\title{
Die intensionele afwyking van die norme van Standaardafrikaans in advertensies
}

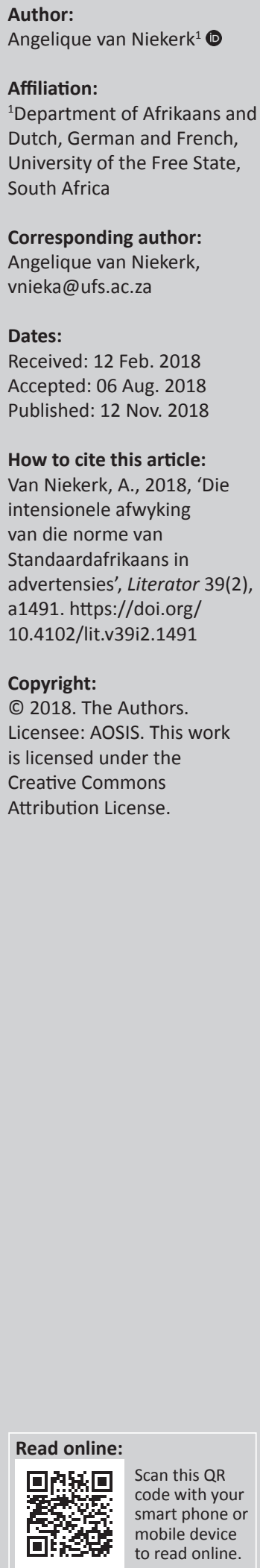

\begin{abstract}
The intentional deviation from the norms of Standard Afrikaans in advertising. The visibility of Afrikaans in the market place (media) and the growth of a different type (nonStandard) of Afrikaans in industries such as the music, film, publication industry, et cetera may be indicative of the symbolic and instrumental positioning of Afrikaans in the market place, in contrast to the hostility sometimes experienced in the tertiary education sector. The advertising industry is one such public sphere where Afrikaans is used. Language is used in a distinct manner in different genres which often deviates in a specific way and for specific reasons from the norms of Standard Afrikaans. To classify language as a deviation implies measurement against one or other norm. In the analytical section of this article, the norms (internal, external and universal) of Standard Afrikaans will be applied to print advertising language to motivate the functionality and acceptance of such (strategic) deviation in the construction of a plausible marketing message. Based on the theoretic principles of text linguistics, the intentionality and acceptance of the deviations of the prescribed norms play a significant role in constructing an implied marketing message. This does not imply the acceptance of unintended language errors but intended deviations of the prescribed norms that have a functional (communicative) market-driven role accepted by the intended audience. The study concludes with an overview of the most evident grammatical characteristics of the Afrikaans language in advertising.
\end{abstract}

\section{Inleiding}

Om taalgebruik as afwykend of normverskuiwend te takseer, impliseer noodwendig dat daar een of ander norm sal wees waarvolgens die taksering geskied. Dit geld ook die taalgebruik in advertensiekommunikasie.

Afwyking of verbreking van die voorgeskrewe taalkonvensies van Standaardafrikaans aan die hand van normatiewe bronne soos woordeboeke en grammatika-beskrywings word soms vereenvoudig en afgemaak as die resultaat van die (verskraalde) tydgees, dit wat kreatief is of foute wat die taal (Afrikaans) bedreig.

Hierdie ondersoek neem bestek op van die grammatika van geskrewe Afrikaans in advertensies (opskrifte en subopskrifte) op verskillende vlakke (interne, eksterne en universele norme). Die deskriptiewe beskrywing van die aard van Afrikaans in die advertensiebedryf (as een van die publieke sfere waarin Afrikaans gebruik word) word volgens ' $n$ bepaalde analiseraamwerk gedoen teen die agtergrond van die hedendaagse tydgees van inklusiwiteit, ekonomiese (mark-) kragte en die aard van die genre, naamlik advertensies.

Die afwyking van die normeringspraktyk in standaardtaal in nasionale hoofstroomtydskrifte die afgelope 10 jaar, kan aan dieeen kantfunksioneel bydraend wees tot die advertensieboodskap, maar aan die ander kant is dit waarskynlik simbolies instrumenteel 'n reaksie op die eise van markkragte wat 'n inklusiewe tydgees onderskryf. Alhoewel die teikenmark steeds 'n (grootliks) homogene Afrikaanssprekende gemeenskap is, is hulle en die sakesektor ook daarvan bewus dat daar in 'n nuwe politieke bestel die verwagting geld dat Afrikaans en sy sprekers meer inklusief (minder normatief uitsluitend) moet word. So beskou, sou die afwyking van die norme van Standaardafrikaans strategies ten doel kan hê om die teikenmark te troos dat hulle Afrikaans en inklusief (verwelkomend is teenoor nie-Standaardafrikaans) is. Dit is dus geen werklike inklusiwiteit wat nagestreef word nie, maar eerder kommersiële uitbuiting van 'n brandende sosiale kwessie. Die behoefte aan inklusiwiteit in Afrikaans word gewoon normatief anders verpak en gekommodifiseer. Hierdie gekommodifiseerde inklusiwiteit sluit dus nóú aan by die argument van Conradie en Van Niekerk (2015:125-126) 
se artikel oor linguistic tokenism, oftewel simboliese skyn. Advertensies is, so gesien, 'n (empiriese) spieël van sosiopolitieke verandering.

Daar is primêr aan hoofopskrifte en subopskrifte aandag gegee omdat dit die sentrum van die fokus is om die aandag van die teikenmark te trek.

In die artistieke speelveld (letterkundetekste, tydskrifverhale, musieklirieke, die digkuns, advertensiekommunikasie) waar taal as instrument gebruik word, is taal noodwendig meer soepel en normverskuiwend as wat normeringskundiges (soos W.A.M. Carstens) of handboeke met goeie reg voorhou.

Die taalsoepelheid blyk op verskillende dissiplinêre taalvlakke uit te speel en in hierdie bydrae sal die taksering van advertensiekommunikasie in terme van spesifiek drie normatiewe vlakke gedoen word, naamlik:

- eksterne norme soos spelling, ortografie, sosiolinguistiek (register en styl) en taalsuiwerheid,

- interne norme soos tekenend uit die morfologie, semantiek, sintaksis,

- universele norme (pragmatiese veranderlikes).

Die onderskeid tussen eksterne, interne en universele norme word in Carstens se Norme van Afrikaans (2011) in die inhoudsopgawe reeds duidelik.

Die uitgangspunt in die artikel is egter nie die uitwys van foute nie, maar die identifisering van funksionele taalspel en doelbewuste afwykings van Standaardafrikaans ter wille van die eise van markkragte in 'n bepaalde sosiopolitieke tydsgewrig waarin inklusiwiteit voorop staan. In die literatuur sou hierna ook as eksterne norme verwys kon word.

Daar word in aansluiting by ander ondersoekers hier ten gunste van die omarming van die normatiewe verskeidenheid van Afrikaans (naas Standaardafrikaans) geargumenteer. Die verskeidenheid in Afrikaans is veral sigbaar in die groter publieke landskap waar Afrikaans in sy verskeidenheid 'n simbolies instrumentele rol vervul in onder meer die musiekbedryf, filmbedryf, sosiale media, uitgewersbedryf, ensovoorts. Selfs by openbare akademiese lesings verklaar sprekers byvoorbeeld dat hulle Omgangsafrikaans gaan gebruik en van die norm van Standaardafrikaans gaan afwyk. (B. Wyngaard, 18 Mei 2018, DF Malherbe-gedenklesing, UV/UFS).

Stell (2010) argumenteer ten gunste van so 'n neutrale variëteit vir groter verteenwoordiging:

Die variëteit valt soms maar niet altijd samen met de prescriptieve Standaardafrikaanse norm. Opname van kenmerken in de prescriptieve Standaardafrikaanse norm zou de stilistische en sociale representativiteit van die norm aanzienlijk kunnen vergroten ... (bl. 441)

\section{Doelwitte}

Hierdie bydrae het ten doel om:

- 'n deskriptiewe oorsig te gee van die grammatikale aard van advertensiekommunikasie in Afrikaans teen die agtergrond van die (preskriptiewe) normatiewe kenmerke van Standaardafrikaans in die literatuur;

- die afwyking van die norme van grammatikale korrektheid van Standaardafrikaans (geskrewe Afrikaans) te verantwoord in die lig van die genre-aard van advertensies, markkragte en die sosio-politieke tydgees van inklusiwiteit.

Die ondersoek sal data uit gedrukte advertensies in hoofstroomtydskrifte teen die normatiewe kenmerke van Afrikaans analiseer ten einde die intensionaliteit en aanvaarbaarheid van die afwyking (in die lig van die geïmpliseerde boodskap) van die norm in die spesifieke advertensies te illustreer. Afrikaanse data (advertensies) is lukraak uit algemene sirkulasietydskrifte tussen 2006-2016 geselekteer. Die seleksieprinsipe vir die artikel het gefokus op die identifisering van een advertensievoorbeeld in elk van die geïdentifiseerde normatiewe kategorieë (wat die basis gevorm het vir die analise-raamwerk) in die literatuur, naamlik interne, eksterne en universele taalnorme. Voorbeelde is ook sodanig gekies dat dit 'n breë tydspan gedurende die afgelope tien jaar beslaan.

Die volgende tydskriftitels is ter sake betreffend die voorbeeldmateriaal in die analise-afdeling: Huisgenoot, You, De Kat, Rooi Rose, Idees. Die advertensies in die datastel is beskikbaar in die openbare domein en wel in verskillende media omdat 'n advertensie nie noodwendig net vir een bepaalde tydskrif geskep word nie. Een van die algemene sirkulasietydskrifte waar die bepaalde voorbeeldadvertensies wel ook in gedrukte formaat verskyn het, is dus deurgaans by die verskillende voorbeelde in die datastel aangedui.

\section{Teoretiese raamwerk}

Die teoretiese raamwerk fokus veral op die normatiewe aspekte van Standaardafrikaans (uit resente standaardbeskrywings van Afrikaans) as teenhanger vir die deskriptiewe analise van die talige aard van gedrukte advertensiekommunikasie. Daar word kortliks op die genre-aard van advertensietaal gewys omdat dit vir die vormkeuses in die teks bepalend is. (Daar is ook heelwat hieroor binne die kommunikasiewetenskap gepubliseer.) Ten slotte word die sosio-politieke tydgees (waarin inklusiwiteit voorop staan) waarin Afrikaans haar in 2018 bevind as 'n belangrike kontekstuele gegewe bygetrek omdat dit 'n impak het op die taalkeuses binne die tydsraamwerk waaruit die data geselekteer is.

Daar is noodwendig ander invalshoeke moontlik, onder meer resepsiestudie (met verskillende teikenmarkte), 'n studie wat op retorika en oorredingskommunikasiepraktyk fokus, maar dit val buite die doelwitte van die bepaalde ondersoek. 


\section{Norme}

Norme het 'n tweërlei aard, naamlik om te rig, byvoorbeeld op taalkundige vlak, maar dit dien ook as beoordelingsmaatstaf. Carstens (2011:2-5) wys in sy naslaanbron 'Norme vir Afrikaans' op die verwarring wat daar rondom begrippe soos goed, korrek, verkeerd, gepas, taalfout, en dies meer bestaan. Hy vestig die aandag daarop dat taalpraktisyns, wat vertalers, kopieskrywers en joernaliste insluit, daagliks met normatiewe kwessies gekonfronteer word. Die begrip norm kan op verskillennde maniere beskou word, naamlik as gedragskode (sosiale afspraak binne 'n gemeenskap), en ook as 'n riglyn, wet of reël (soos in die natuurwetenskappe). In terme van advertensietaal lyk die gedragskodebenadering van Carstens (2011) die wenslikste, want afwyking van die preskriptiewe norme rondom taalgebruik is dikwels aan die orde van die dag, maar dit word (tekstueel) aanvaarbaar in terme van die afspraak met die teikenmark en die aard van die advertensiegenre. Hierdie gedragskodebenadering hang noodwendig nou saam met die koöperatiewe beginsel van Grice (1989) deurdat die intensionele oortreding van beginsels soos opregtheid, relevansie, duidelikheid, ekonomie en hoflikheid dikwels direk tot die skep van 'n geïmpliseerde boodskap bydra (Van Niekerk \& Jenkinson 2012:72).

Webb (1985:77) se standpunt dat daar eintlik nie taalnorme is nie, maar eerder sosiolinguistiese norme wat uit die konteks bepaal wat gepas is, al dan nie, onderskryf die funksionaliteit van die afwyking van die taalnorme in gedrukte advertensiekommunikasie. Carstens (2011:7) stel dit duidelik dat Standaardafrikaans nie altyd die vereiste behoort te wees nie, en baan so die weg vir die funksionele of intensionele aanvaarbaarheid van die afwyking van die riglyne van Standaardafrikaans in advertensiekommunikasie as spesifieke genre.

Taalpraktisyns en kopieskrywers se bewustheid van die grammatiese norme maak die afwyking juis toelaatbaar en funksioneel ter wille van tekswaardering. Hoeken et al. (2009:54) verwys ook na opsetlike afwykings om die intensionele teikenmark te behaag. Daar is natuurlik ontoelaatbare foute (grammatikale slordighede) in advertensies, maar die fokus in hierdie ondersoek is slegs op afwykings wat funksioneel verantwoordbaar is (Carstens 2011:10; De Villiers 1977:2).

Carstens (2011:25) haal onder andere Web (1985) aan as hy duidelik uitlig dat die aard en geldigheid van universele taalnorme en kommunikasienorme hiërargies georden is: '... dit beteken byvoorbeeld dat grammatikale norme soms doelbewus oortree kan word as die eis van kommunikasie dit vereis, soos byvoorbeeld in poëtiese taal'.

In nog een van die standaardwerke binne die Afrikaanse grammatika, 'Afrikaanse tekslinguistiek' lys Carstens (1997:28) sewe kenmerke van tekstualiteit na aanleiding van sy deeglike literatuurstudie wat onder andere De Beaugrande en Dressler (1981) insluit. Die kenmerke is kohesie, koherensie, intensionaliteit, aanvaarbaarheid, informatiwiteit, kontekstualiteit en intertekstualiteit. Daar word in hierdie artikel net op twee van die sewe kenmerke gefokus - juis omdat die aspekte van intensionaliteit en aanvaarbaarheid vir die postulering van die geïmpliseerde bemarkingsboodskap (laaste analisestap) besonder ter sake is. Hierdie is afhanklik van die verhouding tussen die spreker en die hoorder en in hierdie geval die kopieskrywer (spreker namens die handelsmerk) en die bepaalde teikenmark.

Hierdie twee kriteria (naas die ander beginsels van tekstualiteit) beklemtoon die onlosmaaklike skakel tussen die vorm van die boodskap en die bepaalde teikenmark. Simplisties verwoord, beteken dit byvoorbeeld dat 'one size fits all,' oftewel een boodskapvorm vir die hele mark, die genre-aard van advertensietaal binne 'n bepaalde veldtog misken.

Alhoewel enige persoon potensieel 'n bepaalde produk of diens kan gebruik (na die radiostasie luister of die kougom kan koop), is die vergestalting van die boodskap (taal, klank, beeld) op 'n bepaalde teikenmark gerig. Die boodskap wat 'n twintigjarige sportman oortuig om as orgaanskenker te registreer, sal grootliks verskil van die boodskap wat nodig is om 'n volwassene met kinders te oortuig om dieselfde saak te ondersteun. 'n Bepaalde teikenmark sal die spesifieke bemarkingsintensie (intensionaliteit) begryp en boonop aanneemlik (aanvaarbaarheid) vind indien die advertensie-agentskap die nodige navorsing oor die handelsnaam en bepaalde teikenmarkinsigte in die veldtog kon versoen.

Intensionaliteit is ' $n$ belangrike veranderlike in die evaluering van kommunikasie-uitinge. In hierdie studie verreken dit die verhouding tussen die spreker en die hoorder (en hoort dus tuis binne die pragmatiese vlak van taalnormering) waar die verhouding tussen die handelsmerkeienaar en die (kennis of insig van die teikenmark) teikenmark ter sprake is.

Om intensionaliteit as beginsel van tekstualiteit te begryp, moet die aanvaarbaarheid van 'n teks ook verreken word. In die geval van die datastel-advertensies impliseer dit dat die afwyking van die norme van Standaardafrikaans vir die bepaalde teikenmark enersyds intensioneel en andersyds aanvaarbaar moet wees (Carstens 1997:379). Die boodskap is dus iets wat as't ware tussen die spreker en die hoorder onderhandel word op dieselfde manier wat die bemarkingsboodskap die resultaat is van die betrokkenheid van die bepaalde teikenmark by die spreker se boodskap (advertensie) om by die bedoelde bemarkingsboodskap uit te kom. Die bemarkingsboodskap word slegs geïmpliseer soos blyk uit die laaste stap van die analise van elke voorbeeld. Die voordeel hiervan is verhoogde betrokkenheid van die teikenmark by die advertensie wat aandag op die handelsmerk bevorder. 
Swak taalgebruik of grammatikale slordighede is nóg intensioneel nóg aanvaarbaar. Daarom word dit nie deur ' $n$ bewuste taalgemeenskap geakkommodeer nie soos dikwels uit briewekolomme in die koerant en klagtes teenoor die openbare uitsaaiers blyk. Onverantwoordbare afwykings van die norme van Afrikaans en taalfoute val dus om hierdie rede buite die doel van die ondersoek.

Die kwessie van aanvaarbaarheid hang ook nou met die teikenmark se verwagtinge van die genre saam (Carstens 1997:381). Die bepaalde teikenmark behoort 'n bepaalde verwagting van die genre-aard (bv. afwykings van die norme van Standaardafrikaans, die gebruik van onsinnige woorde [geleentheidswoorde], sintaktiese onvoltooidhede) en die handelsmerk te hê (vir die vormlike keuses) indien die handelsmerkeienaar ' $n$ bedoelde boodskap wil oordra. (Die beeld en verwagtinge van 'n handelsmerk soos Verseker (korttermynversekering) teenoor Nando's (gebraaide hoenderkitskos) is byvoorbeeld eiesoortig en konsekwent anders). Die aspek word in geïntegreerde bemarkingskommunikasie (integrated marketing communication [IMC]) as konsekwentheid benoem en dit is vir die bou van 'n handelsmerkbeeld ter sake.

Aanvaarbaarheid en intensionaliteit as twee van die kenmerke van tekstualiteit word binne hierdie kwalitatiewe ondersoek in die analisemodel verreken in die formulering van die geïmpliseerde bemarkingsboodskap. Aanvaarbaarheid word deur sowel Carstens (1997:382) as Renkema (1987:68) met afleiding verbind, en is ook op die ervaring van die gespreksgenote gebaseer. Die advertensieboodskap is weens die genre-aard dikwels op sigwaarde onvolledig en so kripties dat dit onsinnig en ongrammatikaal skyn te wees totdat die bepaalde teikenmark die geïmpliseerde boodskap (bemarkingsboodskap) kan konstrueer. Die wins van betrokkenheid van die bepaalde teikenmark om die korrekte boodskap te kan identifiseer, moet as risiko geweeg word teen die gegewe dat die advertensie se vormlike aard onbegryplik mag wees of dat ' $n$ betekenis oorgedra word wat nie oorspronklik bedoel was nie. Hoeken et al. (2009:56) maak ook hiervan melding in hulle kwalitatiewe ondersoek na die onderskeid tussen vorm en inhoud in 'n bepaalde veldtog.

Ter opsomming kan geargumenteer word dat die Jaguaradvertensie (Figuur 1) as boodskap talle taalfoute bevat. Dit bevat op sigwaarde onlogiese advies vir 'n motoradvertensie; dit is onder meer onduidelik en irrelevant in terme van die koöperatiewe beginsel), hoofletters word foutief aangewend, sintakties is dit onvoltooid ('ELKE $D A G$ ' is nie 'n sin nie), taalvermenging van Afrikaans en Engels kom voor, ensovoorts. Nietemin is 'n bemarkingsboodskap gekonstrueer wat op 'n baie spesifieke teikenmark se behoefte aan adrenalien inspeel wanneer hulle 'n keuse vir 'n motor uitoefen.

\section{Advertensiegenre}

Een van die vernaamste kenmerke van kommunikasie in advertensies as genre is die 'minder is meer'-beginsel. Dit beteken dat die handelsmerkeienaar daarna streef om

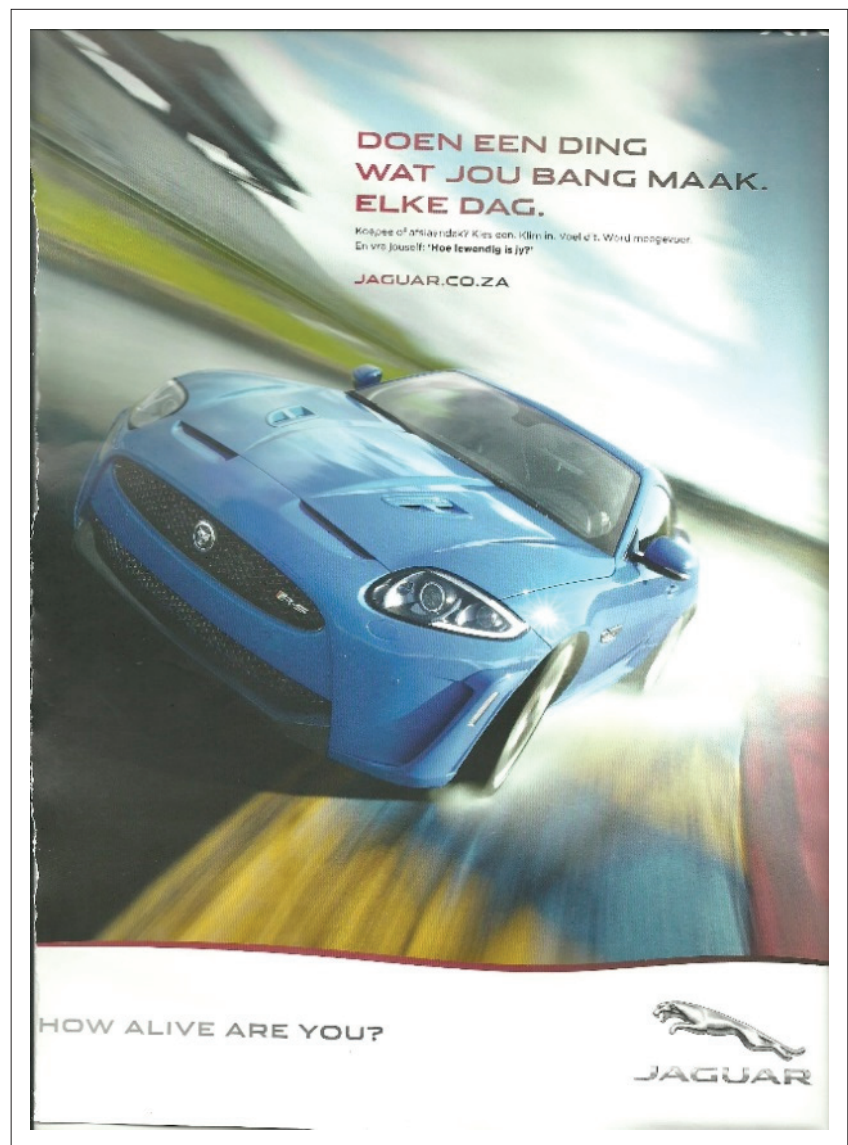

Bron: Jaguar, 2012, 'Jaguar-advertensie', De Kat, Junie, n.p

FIGUUR 1: Jaguar-motoradvertensie.

soveel moontlik met so min as moontlik (teks en woord) te kommunikeer. Dit maak sin in die lig van die tyd en ruimtelike beperkings waarvoor adverteerders moet betaal (Van Niekerk 2008:498).

In die lig hiervan is betekenis in advertensiekommunikasie dig geweef en staan daar in 'n enkele woord, sin of normatiewe deurbrake veel meer as wat op sigwaarde mag blyk. Dit verseker onder meer verhoogde betrokkenheid wat die teikenmark dwing om aandag te gee ten einde van die boodskap sin te kan maak. Die advertensieboodskap word as't ware tussen die handelsmerkeienaar (by monde van die advertensie) en die bepaalde teikenmark onderhandel. 'n Onbedoelde mark sal dikwels nie van die boodskap of implikasie in die advertensie sin kan maak nie, of dit selfs nie aanvaarbaar vind nie.

Dit impliseer dat advertensies nie noodwendig eenduidig kommunikeer nie en in baie gevalle berus die dekodering van die advertensie op die aannames wat die handelsmerkeienaar oor sy nagevorste mark as groep binne 'n bepaalde kulturele en sosiale konteks maak.

Greg Myers gee in sy boek Words in ads (1994) in die inleiding reeds 'n goeie samevatting van die inherente genrekenmerke van advertensietaal waarin aspekte soos die beginsel om meer met minder (woorde, beelde) te kommunikeer, 
grammatikale afwykings, die intertekstuele en stereotipiese aard van advertensies, en so meer ook aandag kry.

Naas die bekende minder-is-meer-beginsel, geld die beginsel van teikenmarkafbakening. Alhoewel die produk of diens (bloedbank, snesies) potensieel byna almal kan insluit, is 'n advertensie en 'n veldtog op 'n bepaalde teikenmark gerig wat by die bepaalde boodskap en bepaalde vormlike vergestalting byval sal vind. 'n Advertensie (veldtog) is daarom nooit op almal gerig nie, maar op 'n spesifiek-bepaalde teikenmark en dit blyk onder meer uit die visuele en talige keuses van die kopieskrywer en grafiese span wat soos in ander vorme van kommunikasie die gedeelde kennis tussen die spreker en die hoorder moet verreken.

In 'n potensiële opvolgstudie en resepsiestudie sou 'n kwantitatiewe ondersoek die resepsie van die bepaalde en onbepaalde teikenmarkte vir bepaalde vormlike keuses byvoorbeeld ondersoek kon word, maar dit val buite die bestek van hierdie ondersoek.

\section{Grammatikale verskeidenheid en taalassosiasie}

Afrikaans word dikwels byna aan die hare in Engelse advertensies bygesleep ter wille van wat Conradie en Van Niekerk (2015:125-126) linguistic tokenism, oftewel simboliese skyn, noem. Dieselfde geld vir die doelbewuste taalvermenging in Suid-Afrikaanse advertensies in Engels of Afrikaans met byvoorbeeld Italiaans, Frans, Duits of die Afrikatale, dikwels net ter aktivering van die taalassosiasie met die bepaalde taalgemeenskap. Die norm van taalsuiwerheid is dan ondergeskik aan die kommunikatiewe doelwit wat taalassosiasie wil oproep. Dit is byvoorbeeld belangrik om Duits in ' $n$ advertensie (woordkeuse of uitspraak in terme van selfs fonetiese skrif) te behou ter wille van die taalstereotipe dat Duitsers (Duitse handelsname) almal presies sou wees (Conradie \& Van Niekerk 2015:124-125). Dieselfde geld vir die soms byna gedwonge invoeging van Afrikaanse kragwoorde soos bliksem, moer, ensovoorts in 'n Engelstalige advertensie primêr ter wille van die stereotipiese assosiasie met Afrikaans-wees en ruheid en sterkte. Dit (sterkte en ruwe aard) is byvoorbeeld juis ter sake wanneer 'n plaasbakkie geadverteer word.

Soms lyk die taalvermenging in die datastel gewoon na taalslordigheid of onsensitiwiteit teenoor die norme van suiwer Standaardafrikaans, byvoorbeeld as 'n Afrikaanse Woolworths-advertensie (Figuur 2) Engelse woorde bevat asof daar geen Afrikaanse ekwivalent vir die woorde 'HealthyFood-items' bestaan nie. Die drie aparte voorbeelde van die linguistiese leksikon healthy, food en items (in dié geval uit Engels as tipe lingua franca in die ekonomiese sektor of medialandskap) kry as't ware 'n uniek individuele status, soos ook blyk uit die afwykende spelling in die advertensie (afwyking op grafiese vlak).

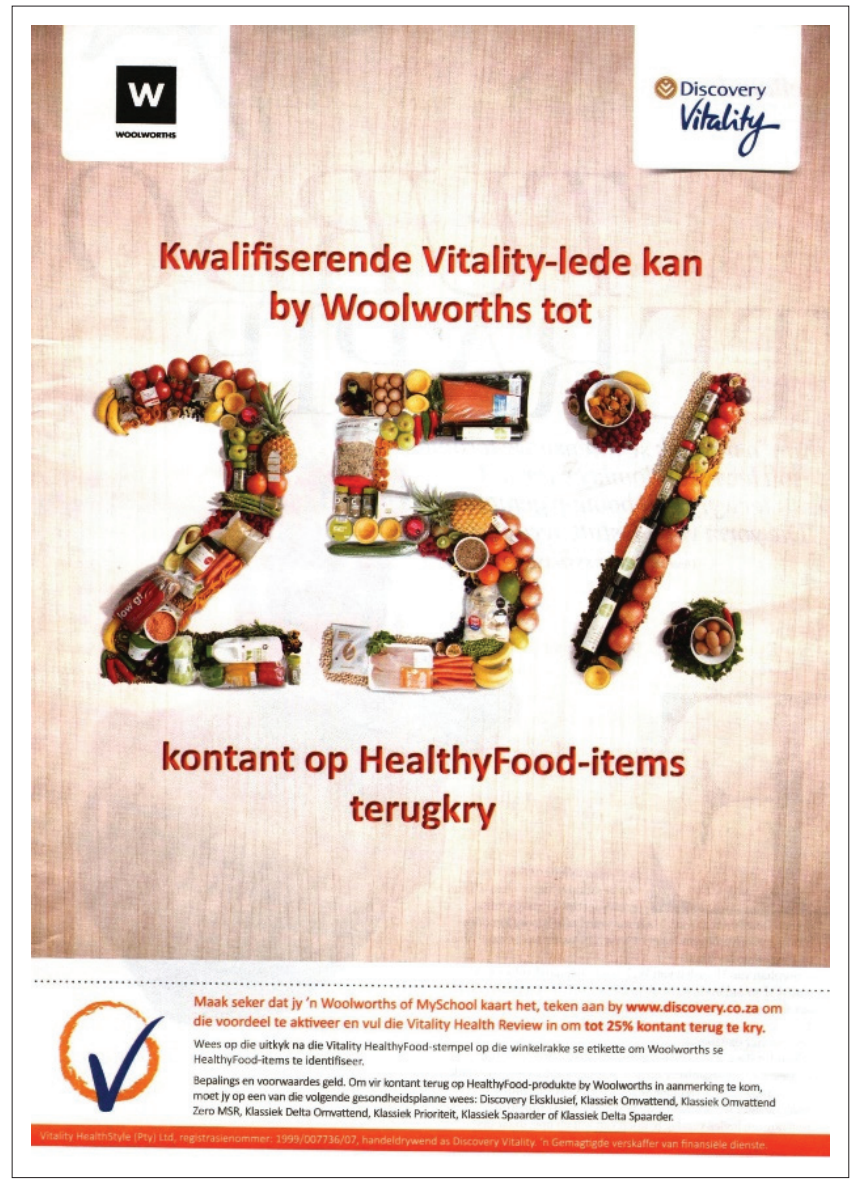

Bron: Woolworths, 2013, 'Woolworths-advertensie', Rooi Rose, Mei, n.p FIGUUR 2: Woolworths-kettinggroep.

Die dinamiese aard van taal bepaal noodwendig dat taalnorme nie rigied kan wees nie en daarom word die opdatering van normatiewe bronne, soos die 'Afrikaanse woordelys en spelreëls' in 2017 kontinu gedoen. Die veranderde taalkonteks in Suid-Afrika, ook in die lig van die skoolkurrikulum, raak byvoorbeeld ook die (dinamiese aard) van Afrikaans direk. Die feit (soos duidelik blyk uit die nasionale kurrikulumverklaring 2008:9-11) dat die groter segment van die Afrikaanssprekende deel van die bevolking nie (meer) noodwendig Afrikaans as skoolvak in graad 12 hoef aan te bied nie, lei tot die aanname dat dit noodwendig 'n impak sal hê op die talige verskeidenheid en afwyking van Standaardafrikaans in die publieke sfeer as sprekers Afrikaans nóg as huistaal nóg as skooltaal aangeleer het (Department of Education, 2008:9-11). Die kwantifisering en beskrywing van sodanige verskuiwing impliseer noodwendig 'n andersoortige ondersoek.

Die inklusiewe sosio-politieke tydgees ten spyt, val die Afrikaanssprekende publiek mekaar soms aan oor woordkeuses in die media en die gebruik van Omgangsafrikaans soos dikwels in briewekolomme in koerante te sien is. In die temapublikasie van die Tydskrif vir Geesteswetenskappe (Junie 2016): 'Oor monnemente gepraat Afrikaans se eerste neëntig jaar' kry die ondersoeker by monde van die gasredakteurs E. Kotzé en F. Pretorius 'n herinnering aan die stryd, groei, teleurstelling en vreugdes 
wat Afrikaans se eerste negentig jaar gekenmerk het. Hulle lewer 'n tersaaklike pleidooi (2016:293) as hulle uit Die Volksblad van 06 Mei 2015 aanhaal:

Die sowat 6.5 miljoen Afrikaanssprekendes in Suid-Afrika sou weer goed doen as hulle hul taal aanwend nie om te vervreem nie, maar om uit te reik, te bemagtig en te omarm.

Daar sou geargumenteer kon word dat die omarming van Afrikaans se verskeidenheid (taalkeuses anders as Standaardafrikaans) deel van hierdie bogenoemde omarming moet wees. Iets daarvan is reeds te merk in die taalkeuses in advertensies, alhoewel die motivering waarskynlik grootliks ekonomies gedrewe is.

Volgens die Statistiek Suid-Afrika se sensusopname van 2011 meer swart-, bruin- en Indiër persone Afrikaans tuis praat, as wit persone. Slegs 2.7 miljoen van die totale 6855082 Afrikaanssprekendes kom uit die sogenaamde wit deel van die bevolking (Statistics South Africa, s.j.).

Afrikaans is nie die taal van ' $n$ homogene sprekergroep nie en daarom sal die vormlike vergestalting van Afrikaans in die publieke sfeer (advertensiebedryf, musiek-, filmindustrie, nuusverslaggewing, ens.) ook nie 'n homogene tipe Standaardafrikaans wees nie. Die analise van die aard van geskrewe Afrikaans in advertensies op verskillende vlakke (interne, eksterne en universele norme) gee so ' $n$ deskriptiewe beskrywing van die aard van Afrikaans in die advertensiebedryf (as een van die publieke sfere) in 'n hedendaagse inklusiewe tydgees.

\section{Die grammatika van 'n lewende taal in die publieke sfeer}

Die databeskrywing bied 'n grammatiese beeld (van verskeidenheid) van Afrikaans wat waarskynlik goed aansluit by Stell (2010:441) wat ten gunste van informele, inklusiewe Afrikaans op basis van die reële en die konteks van Afrikaans in Suid-Afrika argumenteer.

Nog 'n argument om meer inklusief omarmend teenoor verskeidenheid sowel as taalafwykings (soos bv. bedoelde afwykings in musieklirieke, films en spesifiek hier doelbewuste afwykings in advertensies) te wees, is die sigbaarheid en benutting van Afrikaans in die publieke sfeer.

Die afwykings (normatief) in advertensies is meestal wel funksioneel in die lig van die bedoelde boodskap (bv. taalspel) en dus meestal doelbewus. Ander afwykings van Afrikaans wat in die publieke sfeer soos die koerantwese neerslag vind mag soms normatief foutief wees, maar dit moet ook geweeg word in die lig van die instrumentele of simboliese taalgebaar wat markkragte verreken.

Afrikaans het ' $n$ beduidende sigbaarheid in die publieke sfeer (waarvan advertensiekommunikasieboodskappe deel is) soos blyk uit die webblad van Afrikaans.com (2017) ten spyte van 'n klein spreker-populasie. Altesaam $45 \%$ van alle titels wat in Suid-Afrika verkoop word, is in Afrikaans. Gedurende die afgelope tien jaar het die Afrikaanse boekemark verdubbel en 3.6 miljoen Afrikaanse boeke is verkoop.

Daar is wel' $n$ verskraling aan die hoër funksies van Afrikaans in die onderwys, byvoorbeeld met die skrapping van Afrikaans as onderrigtaal aan verskeie universiteite (onder meer aan die UV in 2016).

Kotzé (2014:642) tref 'n baie tersaaklike onderskeid tussen die simboliese en die instrumentele rol wat taal vervul en die term nutsvariëteit naas gebruiksvariëteit. Hy wys tereg daarop dat hoe kleiner die instrumentele waarde van 'n taal, hoe groter is die behoefte aan simboliese uitdrukking. Afrikaans se sigbaarheid in die media (advertensies), uitgewersbedryf, films, musiek, en so meer is tekenend van 'n baie instrumentele rol.

In die 2017-uitgawe van die Afrikaanse Woordelys en Spelreëls (AWS) se inleiding staan daar tereg dat die werkwyse tot opdatering onder meer korpusgedrewe is en ook virtuele korpusse insluit. Die onderskeid tussen skryf- en spreektaal sal noodwendig vir 'n jonger generasie Afrikaanssprekendes vervaag hoe meer taalsprekers ook taalskrywers word in die digitale era. Om 'n roman uit te gee of 'n CD bekend te stel, is kunstenaars lankal of dikwels nie meer aan die keuring van taalpuriste as hekwagters gebonde nie, want selfpublikasie is dikwels die beginpunt van iemand se loopbaan as skrywer, kunstenaar of filmmaker, soos talle grepe op YouTube ook in Afrikaans kan toon. Die situasie het noodwendig 'n impak op die grammatikale aard van 'n lewende taal wat konteksgebonde ook met 'n jonger teikenmark moet kommunikeer.

\section{Analitiese raamwerk Funksionele en aanvaarde afwyking van die norme vir Afrikaans}

In Carstens se boek Norme van Afrikaans (2011:25), word taalnorme op die volgende taalvlakke van toepassing gemaak: fonologiese vlak, morfologiese vlak, sintaktiese vlak, leksikologiese vlak, grafiese vlak, stilistiese vlak en pragmatiese vlak. Die definisie van 'n teks in Carstens (1997:82) is uiters relevant tot die analises wanneer die taalgebruik in advertensiekommunikasie geëvalueer word vir die aanvaarbare intensionele afwyking van die norme van Standaardafrikaans: "n Teks is 'n stuk taalgebruik wat deur die betrokke teksdeelnemers as eenheid ervaar en aanvaar word op sintaktiese, semantiese en pragmatiese gronde'.

Uit die normatiewe taalperspektief soos vervat in onder meer die volgende titels (bronne): Carstens se Norme van Afrikaans (2011); die 2017-weergawe van die Afrikaanse Woordelys en Spelreëls (AWS), Carstens se Afrikaanse tekslinguistiek - 'n inleiding (1997), Carstens en Bosman (reds.) se Kontemporêre Afrikaanse taalkunde (2014), Müller se Skryf Afrikaans van A tot Z (2003) en nog meer, sou daar wel geoordeel kan word dat advertensietaal die norme 
van Standaardafrikaans op die volgende vlakke dikwels funksioneel of intensioneel misken:

\section{Vlakke van normafwyking}

Die volgende vlakke van normafwyking (eksterne, interne en universele norme) soos gelys uit die literatuur en die teoretiese afdeling van die ondersoek, sal geld:

- Die grafiese norme van Afrikaans wat skryfkonvensies, spellingnorme en leestekenkonvensies insluit, is as kriteria gebruik.

- Die leksikonograaf van Afrikaans is as kriterium gebruik betreffend betekenisverbreding en norme van duidelikheid.

- Die sintaktiese norme wat die gebruik van bysinne as hoofsinne, sintaktiese onderleksikalisering en onvoltooide sinne bepaal, word in die analises gebruik.

- Die stilistiese norme van registervoorskrif, taalsuiwerheid en welvoeglike taal word as kriterium van analise gebruik.

- Die geledingsreëls van die morfologie word in die gebruik van geleentheidswoorde en onsinnige woorde verreken.

- Die pragmatiese norme met betrekking tot koöperatiewe samewerking teen die agtergrond van gedeelde kennis word as kriterium op die datastel toegepas.

- Die tekstuele norme van Afrikaans (Carstens 1997:71108) vereis onder meer dat die aanvaarbaarheid van die teks evalueer word in die lig daarvan dat die teks (advertensie) as eenheid deur die (bepaalde) teikenmark aanvaar moet word.

Bogenoemde norme sluit direk aan by die vrae wat Carstens (2014:344) aan die teksredakteur rig om die regte keuses vir die toepaslike konteks te maak. Hierdie norme en keuses word verder in die analises op die advertensievoorbeelde in elke kategorievoorbeeld in die analise-afdeling toegepas.

\section{Analise}

In die analitiese afdeling van die ondersoek word daar op die bogenoemde normeringsvlakke telkens 'n tipiese voorbeeld, tekenend van onder meer die normafwyking van Standaardafrikaans gebruik, ter illustrasie van die funksionele oortreding van die norme in die lig van die bedoelde bemarkingsboodskap. In die kategorieë waar daar meer as een duidelik onderskeibare subkategorie normafwyking geïdentifiseer kan word, word 'n tipiese voorbeeld van die normafwyking in Afrikaans in elk van die subkategorieë ingesluit. Die analise fokus op die punt van aandag (opskrif en subopskrif) in die advertensie en dit is nie bedoel om 'n volledige talige analise van die hele advertensie te wees nie.

Die analise moet noodwendig teen die agtergrond van die aard van advertensiekommunikasie gedoen word wat vanweë die genre se aard eiesoortig anders lyk as Standaardafrikaans. Die analises maak dit wel moontlik om 'n grammatikabeskrywing van gedrukte advertensiekommunikasie te gee. Dit sou in toekomstige vergelykende ondersoeke van nut kon wees om byvoorbeeld die aard van verandering op taalvlak in hedendaagse advertensiekommunikasie te vergelyk met advertensies van dertig en meer jaar gelede uit dieselfde tydskrifte.

\section{Formaat van die analises}

Die formaat van aanbieding wat die analitiese aspek betref, is soos volg:

- Normeringsvlak en subkategorie ter sake.

- Voorbeeld in Jpg.-formaat en handelsnaam.

- Bron en die datum van die advertensie.

- Talige fokus in terme van die norme van Afrikaans (direkte aanhaling uit die advertensie).

- Normatiewe teenhanger in terme van Standaardafrikaans.

- Tekstuele ondersteuning uit die advertensie ter wille van 'n aanvaarbare en intensionele bemarkingsboodskap.

- Geïmpliseerde bemarkingsboodskap vir die bepaalde teikenmark.

\section{Grafiese vlak}

\section{Skryf- en spelkonvensie:}

- Spur-restaurantgroep (Figuur 3)

- Huisgenoot, Maart 2007

- $300 \mathrm{~g}$ RIBBETJIES + 1/4 HOENDER of $125 \mathrm{~g}$ CALAMARI = SPURFEK!

- Spur-restaurantgroep bied 'n perfekte ete bestaande uit 300 gram ribbetjies en 'n kwart porsie hoender of 125 gram calamari teen R49.95 aan.

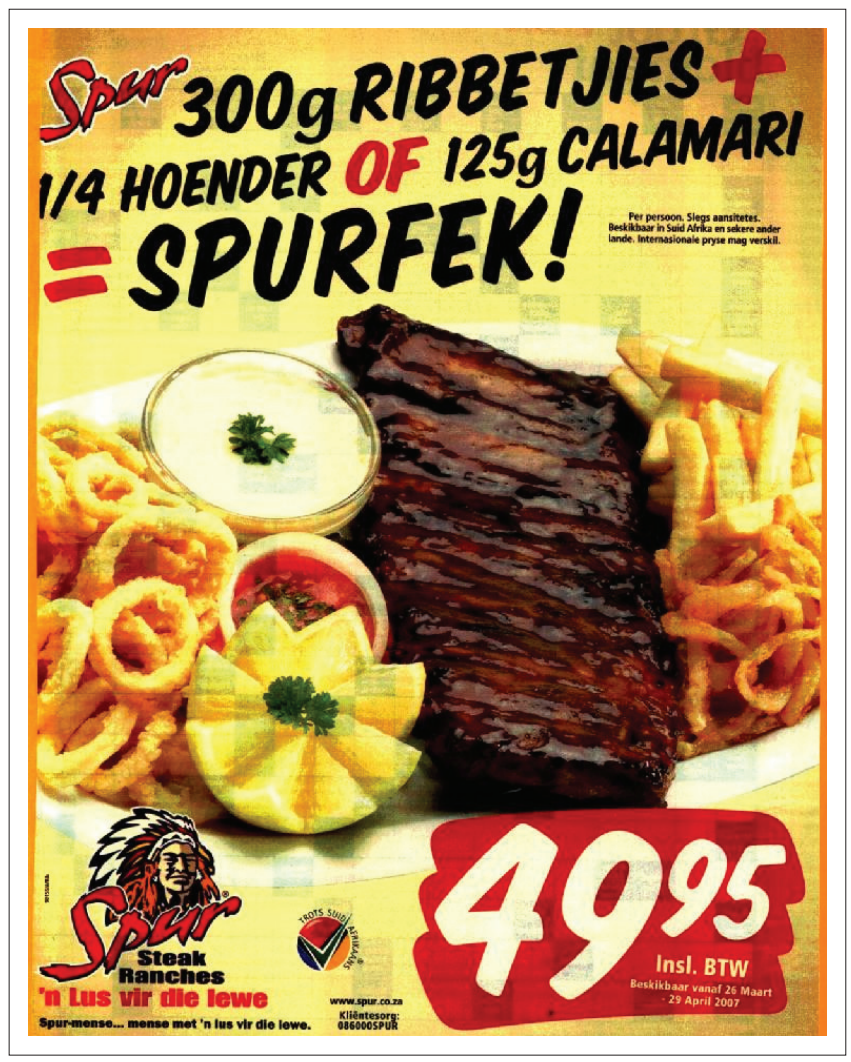

Bron: Spur, 2007, 'Spur-advertensie', Huisgenoot, Maart, n.p FIGUUR 3: Spur-restaurantgroep. 
- Die normatiewe vereistes met betrekking tot die gebruik van hoofletters, die gebruik van kommas en die gebruik van woorde in plaas van wiskundige simbole in die geskrewe taal word hier (ter wille van 'n korter skryfstyl getrou aan die genre van advertensiekommunikasie) negeer. Natuurlik is hier ook velerlei oor die afwyking van die norme van die morfologie ter wille van die insluiting van die handelsnaam Spur te sê, maar daar sal in 'n ander voorbeeld spesifiek na die afwyking van die morfologiese norme van Afrikaans gekyk word. Die bepaalde teikenmark se voorafkennis (pragmatiese vlak) van die tipe kos wat Spur bedien en die aard van die restaurant (informele kuierplek wat spesialiseer in vleisgeregte soos biefstuk, burgers, ribbetjies, ens.) help met die begrip van die bemarkingsboodskap ten spyte van die onderleksikalisering en die afwyking met betrekking tot leestekens en die gebruik van geleentheidswoorde soos 'spurfek' as 'n kombinasie van Spur en perfek.

- Die geïmpliseerde boodskap is: Spur-restaurante het die volgende perfekte aanbieding beskikbaar teen R49.95: 300 gram ribbetjies, 1/4 porsie hoender of 125 gram calamari.

\section{Spelling en hoofletters:}

- Radio Sonder Grense (RSG) radiostasie (Figuur 4)

- Huisgenoot, Julie 2015

- Hoofopskrif: Ven kerkorrel tot Kerkorrel

- Subopskrif: Van Dis Gospel tot Oppiradio.

- RSG radiostasie speel 'n verskeidenheid tipes musiek wat kerkorrelmusiek, musiek soos dié van Johannes Kerkorrel en gospel insluit.

- Die taalspel (vanweë die voorkennis van die bepaalde teikenmark) tussen kerkorrelmusiek en die alternatiewe musiek van die sanger Johannes Kerkorrel is tekenend van die verskeidenheid en variasie waarvoor RSG wil bekend staan. Dit blyk ook talig uit die foutiewe spelwyse of die behoud van die assimilasie in die subopskrif: 'oppiradio' in plaas van 'op die radio'. Dis trouens ook die naam van een van die musiekprogramme, 'oppiradio'. Die niestandaardspelling het dus 'n funksionele benoemingswaarde wat met die aard van

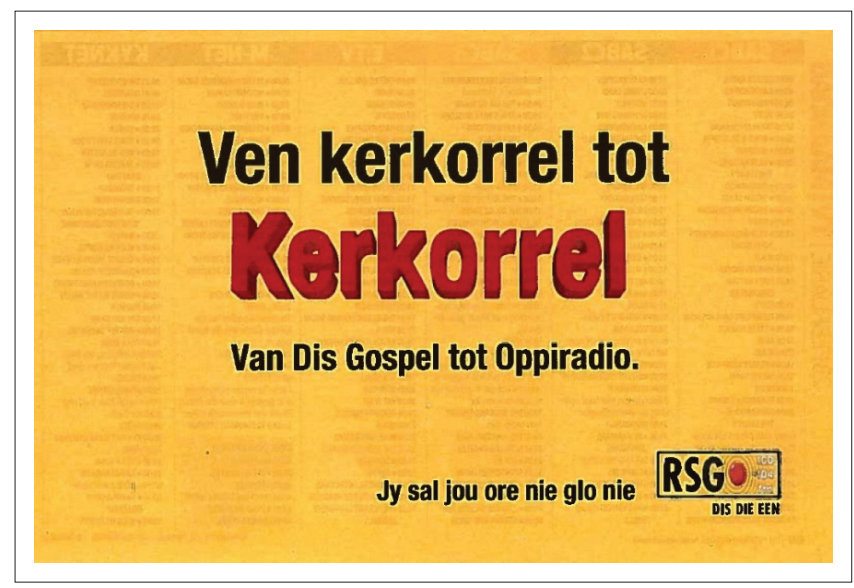

Bron: Radio Sonder Grense, 2015, 'Radio Sonder Grense-advertensie', Huisgenoot, Julie, n.p FIGUUR 4: Radio Sonder Grense- (RSG) radiostasie. die musiekprogram verband hou. Die oënskynlike spelfout in 'ven' waar ons normatief 'van' verwag, boots op klankvlak iets na van die uitspraak van byvoorbeeld Engelstalige sprekers (nie huistaalsprekers nie) wanneer hulle Afrikaans praat. Daar sou geargumenteer kon word, dat die afwyking (variantegebruik) in die gebruik van hoofletters en leestekens soos punte in die hoofopskrif en subopskrif trouens in pas is met die (relatiewe) vrye aard van die bepaalde radioprogram.

- RSG-radiostasie is inklusief en verteenwoordigend van baie smake soos wat ook in hulle musiekaanbod en ander programmeblyk. Diemusiekaanbod sluitkerkorrelmusiek en ook musiek van sangers soos Johannes Kerkorrel, asook gospelmusiek in. Hierdie variasie vind jy alles op die radiostasie se program 'oppiradio', 'n stasie waar mense ook oppiradio kan en mag sê.

\section{Spellingkonvensie:}

- TV-program: Republiek van Zoid Afrika (Figuur 5)

- Huisgenoot, Junie 2015

- Hoofopskrif: REPUBLIEK VAN ZOID AFRIKA

- Subopskrif: Die president is terug vir seisoen 2

- Begin 2 Julie 2015

- Op twee Julie begin die tweede seisoen van die reeks Republiek van Zoid Afrika met Karen Zoid as aanbieder op kykNET, 'n Suid-Afrikaanse TV-stasie.

- Noodwendig is hier ook heelwat intertekstuele inspeling (pragmatiese vlak) en sal slegs die bepaalde teikenmark

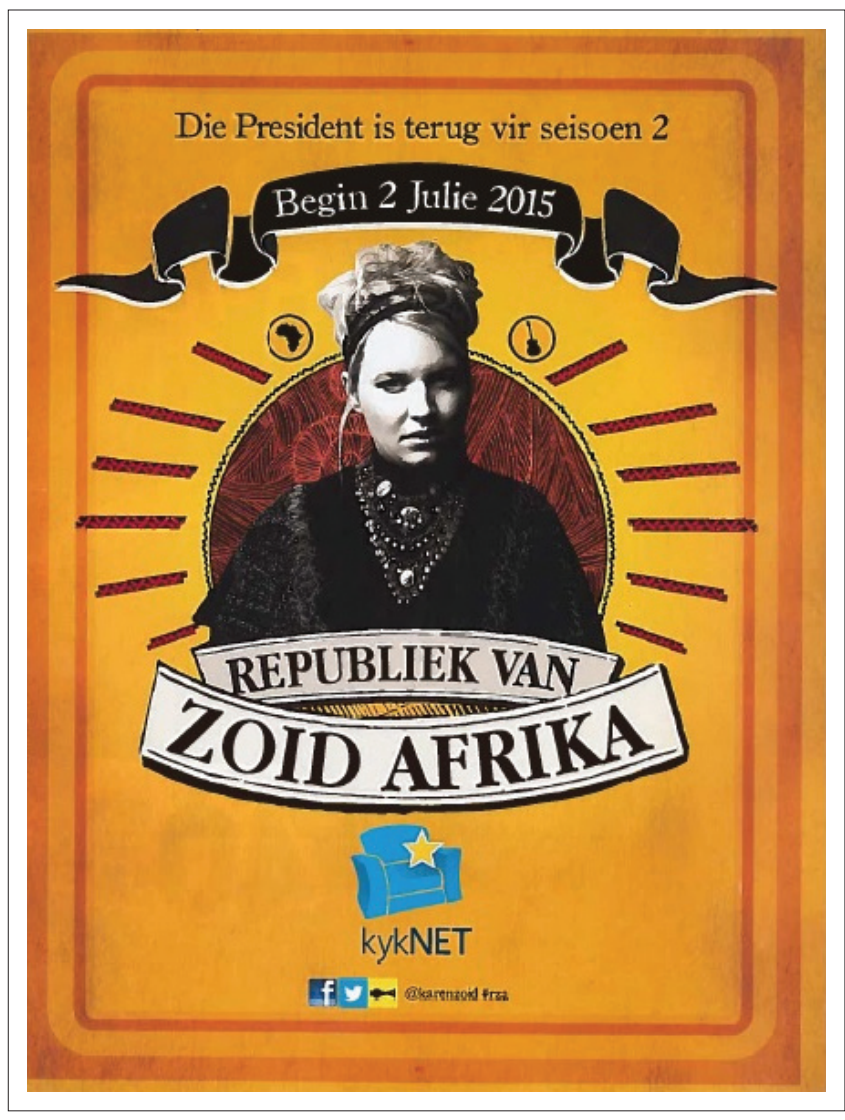

Bron: Republiek van Zoid Afrika, 2015, 'Advertensie vir Republiek van Zoid Afrika', Huisgenoot Junie, n.p

FIGUUR 5: TV-program: Republiek van Zoid Afrika. 
wat Karen Zoid as bekende ster in die Suid-Afrikaanse vermaaklikheidsbedryf ken en diegene met voorkennis van die vorige reeks Republiek van Zoid Afrika die geïmpliseerde boodskap snap. Die kaartafdruk van Suid-Afrika en die kitaarprentjie help om die nodige agtergrondkennis (Afrikaanse rock-sangeres as aanbieder en bekendes in Suid-Afrika is die gaste) te aktiveer. Die norme met betrekking tot die gebruik van leestekens is ook afwesig wat ook inpas by die vry land met sy divapresident wat allesbehalwe konvensioneel is. Die norme met betrekking tot die gebruik van hoofletters is aangepas en waarskynlik logies te verantwoord omdat dit soos 'n naam of banier regoor die advertensie aangebied word.

- Die Afrikaanse Rock-sangeres, Karen Zoid, is die aanbieder van die TV-program Republiek van Zoid Afrika waarin sy as diva-president onderhoude voer met die voorste Suid-Afrikaanse denkers, dromer en leiers van haar keuse voor die TV-volk in haar (TV-)land, Zoid Afrika.

\section{Leksikologiese vlak}

\section{Afwykende betekenistoepassing en betekenisverbreding:}

- Opvoedkundige promosie-artikel van die internasionale bewaringsorganisasie WWF (Figuur 6)

- Huisgenoot, Februarie 2010

- 'Panda-monium - 'n groot stryd om oorlewing'

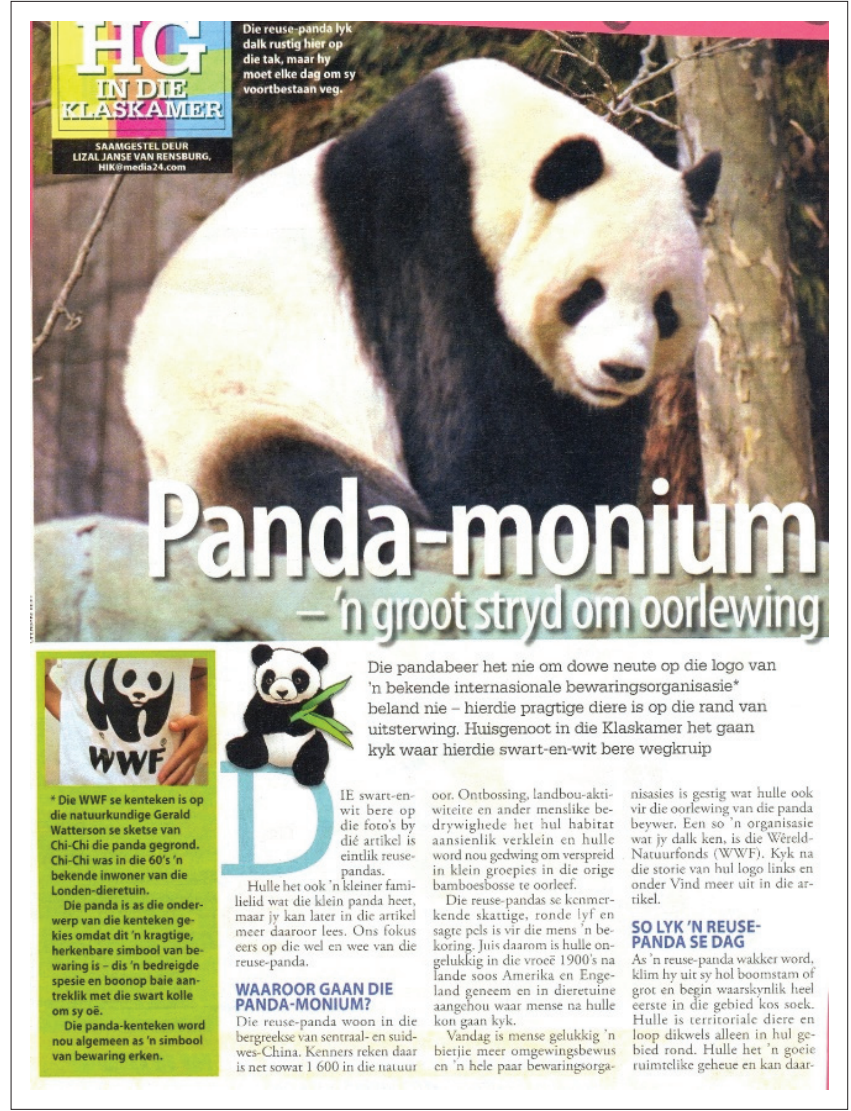

Bron: WWF, 2010, 'World Wide Fund for Nature-advertensie', Huisgenoot, Februarie, n.p FIGUUR 6: Bewusmakingsveldtog vir die internasionale bewaringsorganisasie (WWF) wat fokus op die pandabeer.
- Die pandabeer ondervind pandemonium met oorlewing weens omgewingbewaringsprobleme.

- Die inspeling op morfologiese vlak deur die skepping van 'n geleentheidswoord uit die kombinasie en wysiging van panda en pandemonium trek natuurlik dadelik die aandag. Die reeds bekende simbool van bewaring in die vorm van die pandabeer dra ook by tot die konstruering van 'n aanvaarbare bemarkingsboodskap vir die bepaalde teikenmark ten spyte daarvan dat hier op vele vlakke op sigwaarde normatief oortree word wat die vereistes van Standaardafrikaans betref.

- Bewaring verdien ons erns, want dit kan 'n pandemonium veroorsaak as diere soos die panda uitsterf.

\section{Duidelikheid:}

- Dentyne kougoum (Figuur 7)

- Idees-tydskrif, Junie 2010

- Asemrowend

- Subopskrif: Dentyne gee jou rede om te glimlag.

- Dentyne-kougom se impak op jou higiëne, asem (reuk) en gevoel in jou mond is verbasend goeie nuus.

- Die promosie-advertensie verskaf al die tersaaklike ondersteuning vir beide die letterlike en figuurlike betekenisse, alhoewel die betekenis van asemrowend konvensioneel nie met die reuk van 'n vars asem verband hou nie. Die letterlike en figuurlike betekenis word in een woord binne die konteks van die advertensie met die glimlaggende mense teen die agtergrond van die see byeengetrek. Dit is tipies van die genre-aard van

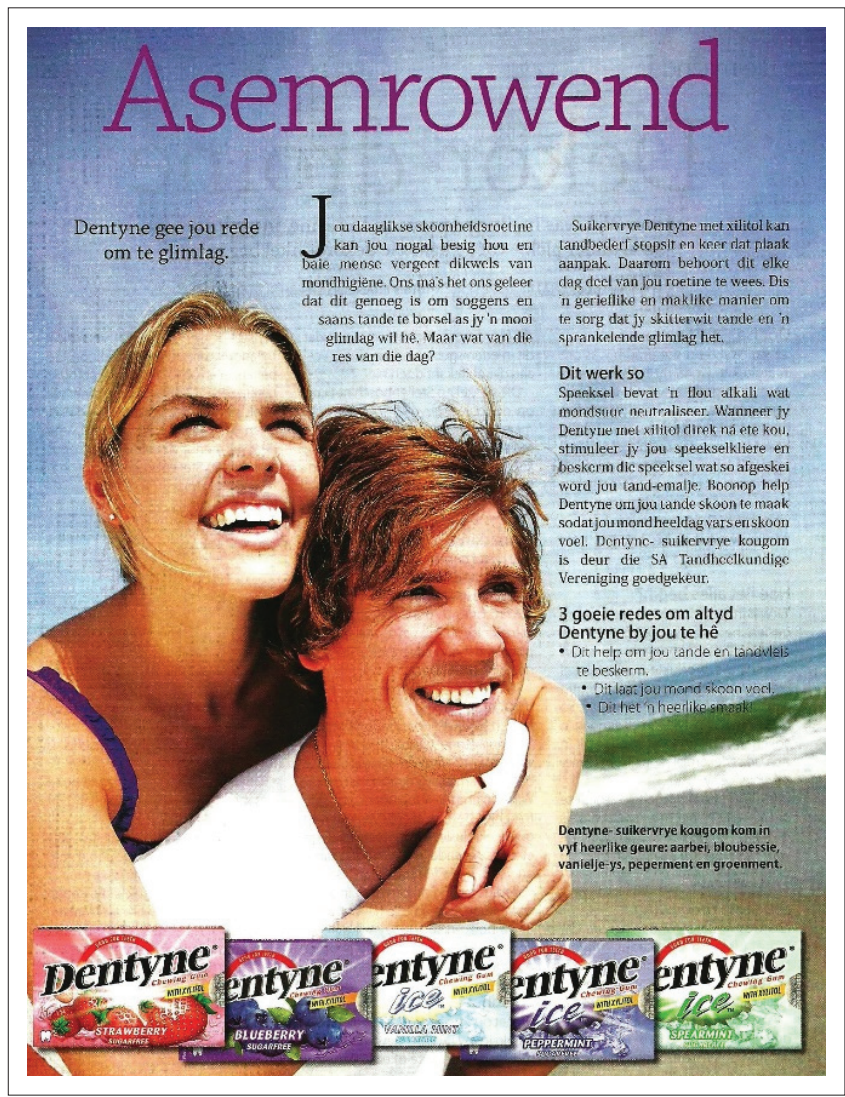

Bron: Dentyne, 2010, 'Dentyne-advertensie', Idees, Junie, n.p

FIGUUR 7: Dentyne-kougom. 
advertensies om meer met minder woorde te sê en in hierdie geval met die woord asemrowend.

- Jou asem sal seevars wees as jy Dentyne gebruik en daarom het jy letterlik (higiëne, reuk, voel) en figuurlik rede om te glimlag.

\section{Sintaktiese vlak}

\section{Die bysin word as hoofsin ingespan:}

- Vitaforce-vitamienaanvullling (Figuur 8)

- Huisgenoot, Junie 2006

- OMDAT VROUE UITBLINK

- Vitaforce het 'n vitamienaanvulling Ladyvite ontwerp spesfiek vir vroue omdat hulle uitblink en ekstra aanvulling benodig vanweë hulle prestasie.

- Die ontbrekende hoofsin moet uit die tekstuele leidrade herwin word. Die miskenning van die gebruik van hoof- en kleinletters val natuurlik ook op maar die ooraanwending van hoofletters in die hoofopskrif kan funksioneel verband hou met die uitblinkkwaliteit (staan letterlik en figuurlik uit) wat aan vroue in die advertensie toegeskryf word. Die gebruik van die planetebeeld, spesifiek Venus, trek ook aandag vanweë die gedeelde intertekstuele kennis op basis van boeke soos Men are from Mars, women from Venus, ensovoorts. Die gedeelde kennis waarop die teikenmark ter wille van aanvaarbaarheid moet inkoop, vorm as't ware die hoofsin vir die bysin 'omdat vroue uitblink' en daardeur word die onvolledige boodskap op sigwaarde na betrokkenheid van die bepaalde teikenmark 'n sinvolle geheel.

- Vroue blink uit en het ander vitamienbehoeftes (as mans) vanweë hulle (dinamiese) aard en daarom het Vitaforce spesifiek Ladyvite ontwikkel om aan vroue se unieke behoeftes te voldoen.

\section{Ongrammatikale eenheid sonder 'n werkwoord (onderleksikalisering):}

- Oranjerivier-wynkelders (Figuur 9)

- Jou oomblik. Ons wyn.

- Oranjerivierkelders het wyn vir elke geleentheid.

- Voorafkennis wat betref die bepaalde teikenmark se gewoonte om spesiale oomblikke met 'n glasie wyn te vier, asook voorafkennis en inskatting van die toneel in 'n wild- en natuurpark waar'n perfekte sonsondergang help om die ontbrekende werkwoorde (verskaf en ervaar) in te vul: Ons verskaf die perfekte wyn wanneer jy (jou) die perfekte oomblik ervaar.

- Vier en geniet elke perfekte oomblik of geleentheid in jou lewe met die wyn van Oranjerivier-kelders.

\section{Onderleksikaliering:}

- Nutriphase-hondekos van PicknPay (Figuur 10).

- Rooi Rose, Januarie 2014

- Bereik totale balans

- Nutriphase-hondekos is gebalanseerde kos vir jou hond.

- Voorafkennis van aktiwiteite soos joga of pilatesoefeninge in gimnasiums of studio's waar mense

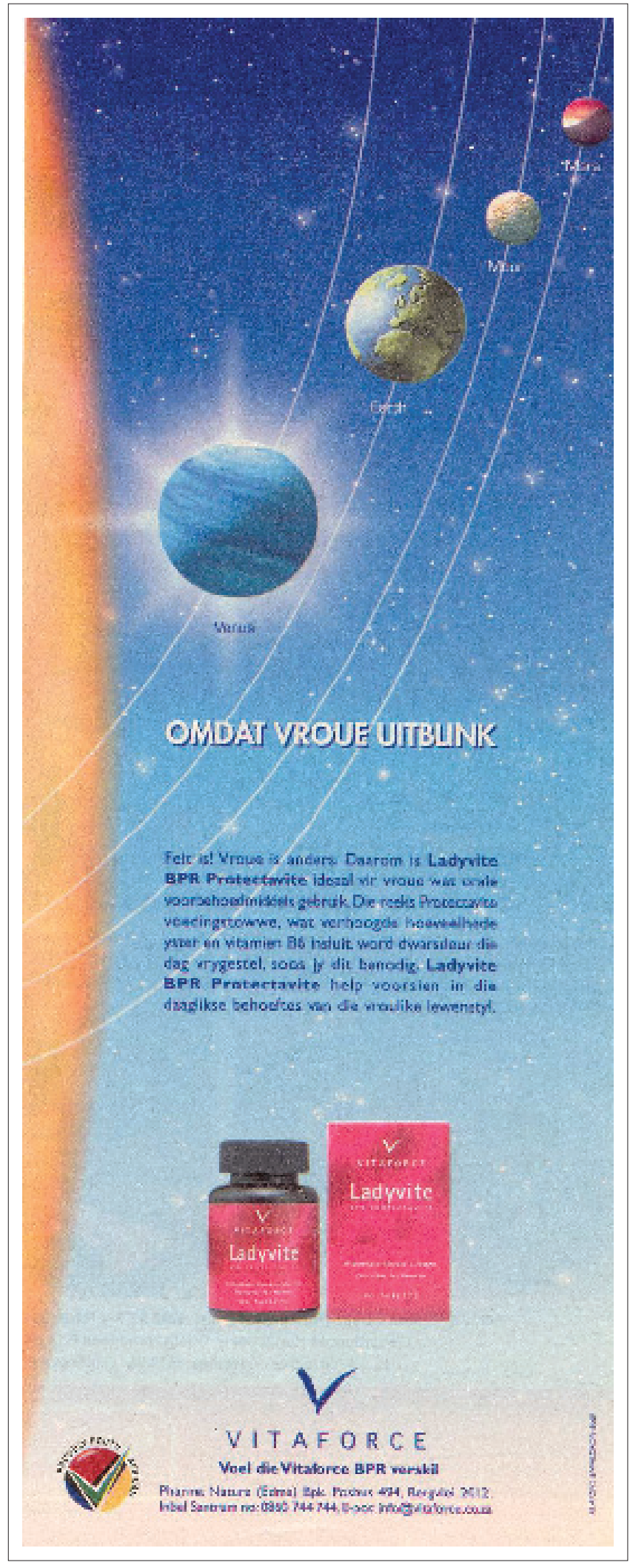

Bron: Vitaforce, 2006, 'Vitaforce Ladyvite-advertensie', Huisgenoot, Junie, n.p

FIGUUR 8: Ladyvite multi-vitamienaanvulling vir vroue is deel van die Vitaforce handelsnaam.

hulle liggame fiks en gesond hou, sal die bepaalde teikenmark help om die tipiese joga-mat waarop die hond sit met hondekos te skakel wat deur PicknPay verkoop word. Die aandag val byna onmiddellik juis op 


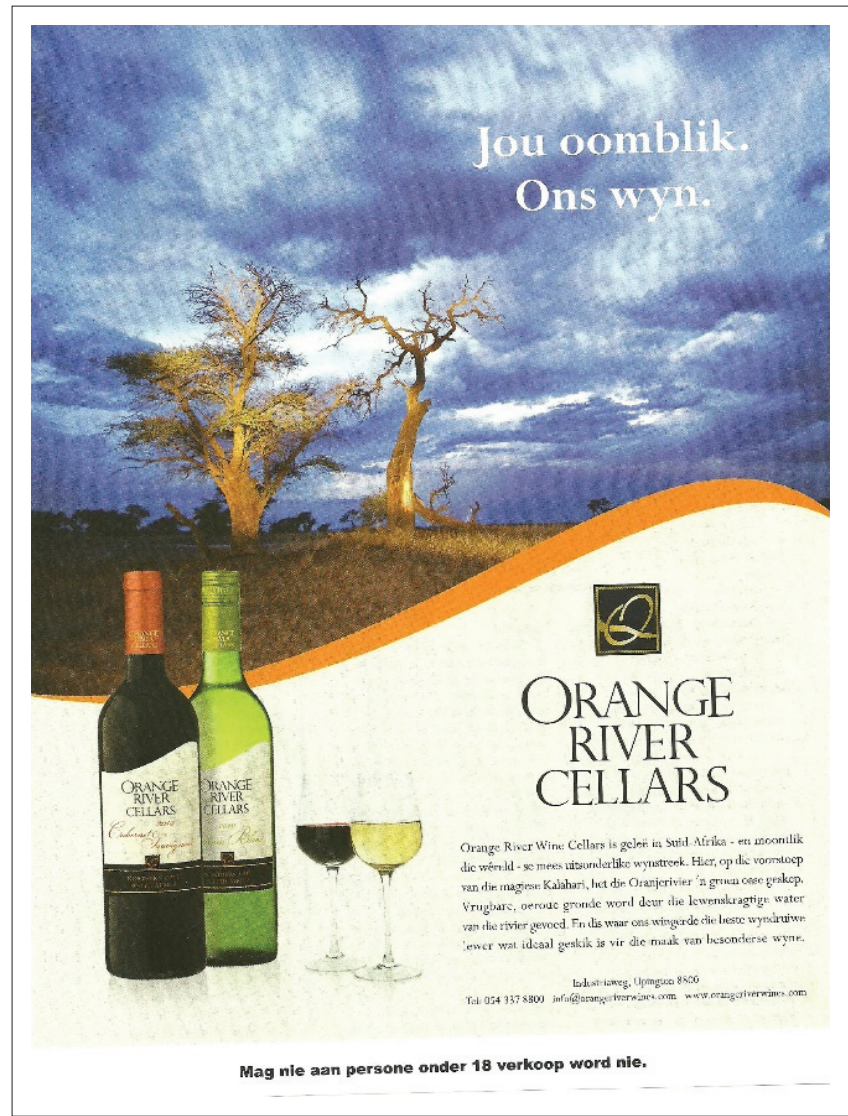

Bron: Orange River Cellars, 2012, 'Orange River Cellars-advertensie', Huisgenoot, Junie, n.p. FIGUUR 9: Orange River Cellars-wynkelder.

die hond in 'n tipiese joga-strekposisie op 'n joga-matjie en dit noop die teikenmark om self sin te maak van die bemarkingsimplikasie wat vanweë die oënskynlike irrelevansie tussen joga en hondekos ontstaan.

- Nutriphase gee die nodige balans aan jou hond se liggaam byna soos wat joga op 'n letterlike vlak aan jou (jou hond) doen.

\section{Stilistiese vlak}

\section{Taalsuiwerheid:}

- TV-kanaal en TV-program, 7 de Laan op SABC 2 (Figuur 11).

- You tydskrif (Afrikaanse uitgawe: Huisgenoot), November 2008

- 'n Straat waar almal parkeerplek vind.

- Subtitle: A street where everyone finds parking.

- Die TV-reeks 7de Laan, verskaf figuurlik gesproke vir alle taalgroepe ' $n$ tuiste vanweë die feit dat dit ook ondertiteling in Engels verskaf.

- Dit is talig opvallend dat een advertensie tegelykertyd in twee tale aangebied word soos wat die praktyk is met films of TV-reekse waar daar van ondertiteling gebruik gemaak word. Normatief is die byna gedwonge invoeging van 'n vertalingsekwivalent onder die subopskrif 'subtitle' vir die Afrikaanse hoofopskrif in 'n Engelse tydskrif opvallend. Advertensies praat normaalweg met ' $n$ bepaalde teikenmark in ' $n$ bepaalde taal en vertaling is dus nie 'n vereiste of konvensioneel te verwagte in gedrukte advertensies nie. Die ontbrekende werkwoord

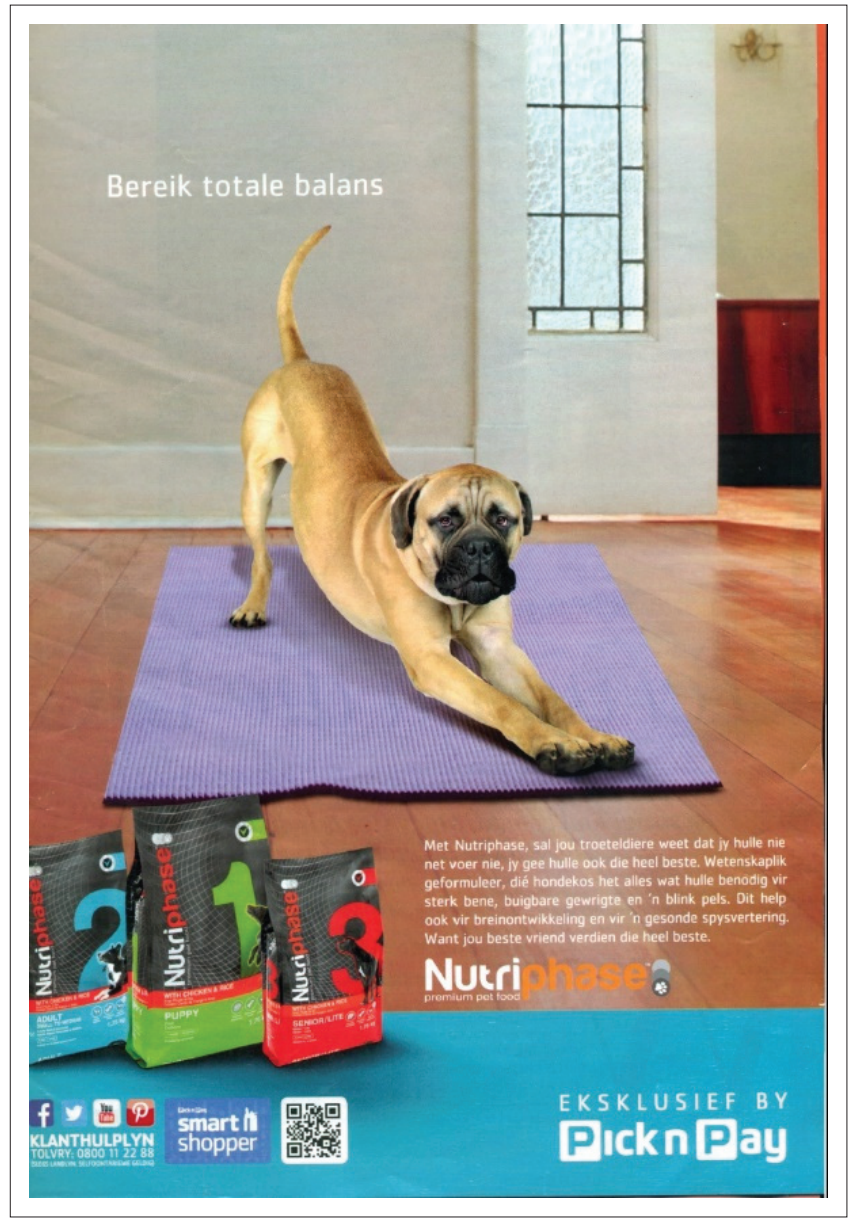

Bron: Nutriphase, 2014, 'Advertensie vir Nutriphase eksklusief by Pick n Pay', Rooi Rose, Januarie, n.p.

FIGUUR 10: Nutriphase-hondekos van Pick $n$ Pay.

in die opskrif (onderleksikalisering) herinner aan die spreektaal en dit sou funksioneel geag kon word teen die agtergrond van die informele gesprekstyl van die TV-sepie. Die TV-program, 7de Laan, het 'n inklusiewe benadering tot die demografiese en talige verskeidenheid van Suid-Afrika waarmee hulle uiteenlopende kykers wil bereik. Die bepaalde teikenmark wat vertroud is met die program en dus oor die nodige voorkennis (pragmatiese vlak) beskik, sal die uitleg in die vorm van ondertiteling, die informele spreektaalregister en die rede vir die ekwivalente gebruik van Afrikaans en Engels in die advertensie waarin alle rassegroepe in harmonie saamleef, begryp.

- Die TV-program 7de Laan, op SABC 2 wil Suid-Afrikaners almal laat tuis voel en die program word in meer as een taal uitgesaai met die ondertiteling in Engels.

\section{Welvoeglikheid en skryftaalregister:}

- BabySoft-toiletpapier (Figuur 12)

- Huisgenoot, November 2015

- Hierdie's nie een van daai seksie parfuum-advertensies nie. Net 'n bakgat manier om jou agterent skoon te hou.

- Die normatiewe vereistes met betrekking tot skryftaal en spreektaal word met die gebruik van woorde soos hierdie's en daai en seksie en die norme met betrekking tot 


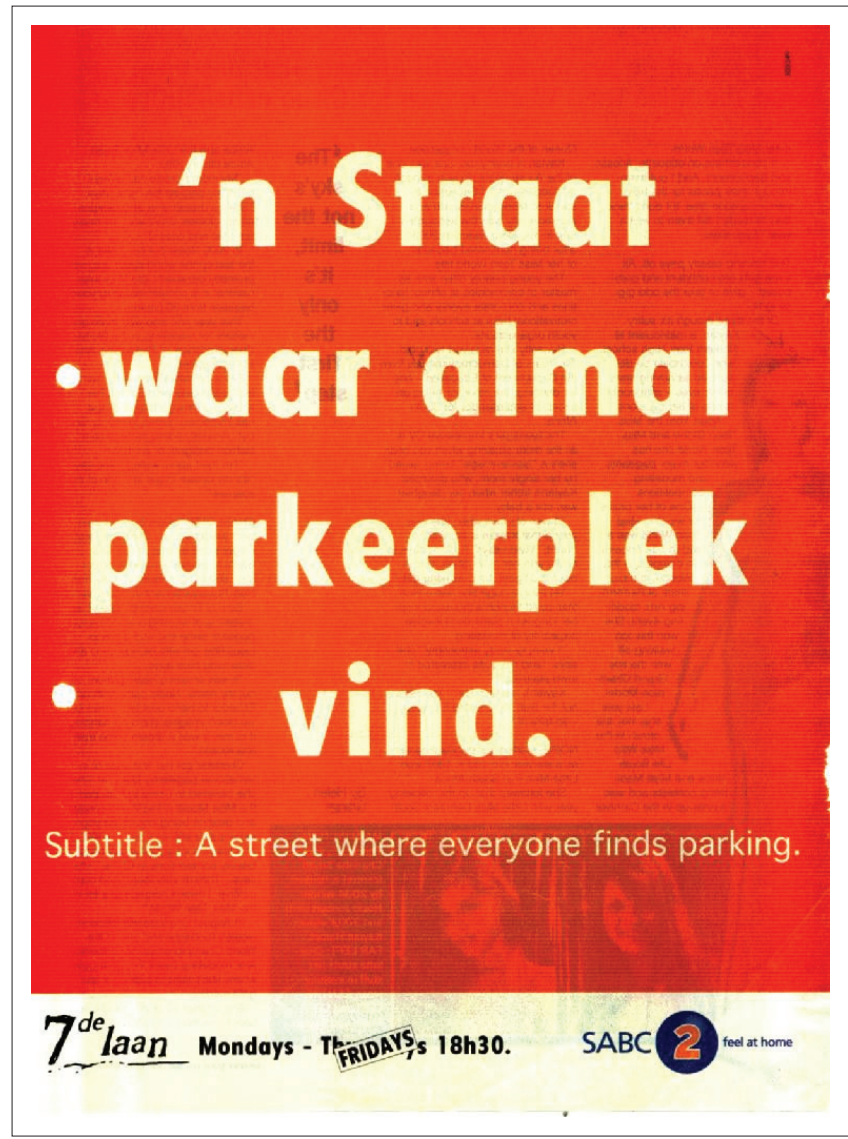

Bron: 7de Laan, 2008, 'Advertensie vir die sepie 7de Laan', You [Afrikaanse uitgawe: Huisgenoot], November, n.p

FIGUUR 11: 7de Laan televisie-sepie.

welvoeglikheid in terme van skryftaalregister word verbreed as gevolg van woordkeuses soos bakgat, agterent, ensovoorts weens die semantiese inspeling op menslike uitskeiding, private liggaamsdele en toiletgewoontes. BabySoft posisioneer nie hulle produk as 'n sensuele produk (soos wat die geval is met parfuum-advertensies) nie, maar as 'n ideale toiletpapier wat jou skoon en vars laat voel, byna soos parfuum.

- Die intertekstuele inspeling en voorafkennis (pragmatiese vlak) oor hoe rooskleurig produkte soms voorgestel word en waardeur die bepaalde teikenmark mislei kan voel, is ter sake agtergrond waarop die bepaalde teikenmark moet inkoop om te aanvaar waarom die handelsmerkeienaar kies om die produk te kontrasteer met sensuele parfuumadvertensies.

- BabySoft is 'n ideale toiletpapier om aan jou higiëniese behoeftes in die privaatheid van jou badkamer te voldoen.

\section{Morfologiese vlak}

\section{Geleentheidswoord:}

- Flake-sjokolade van Cadbury (Figuur 13).

- Huisgenoot, Maart 2006

- Sjok-behandeling. Vir Liefdes-probleme.

- Om 'n Flake sjokolade te eet is soos om in 'n liefdesverhouding te wees waarin jy geen weerstand het nie.

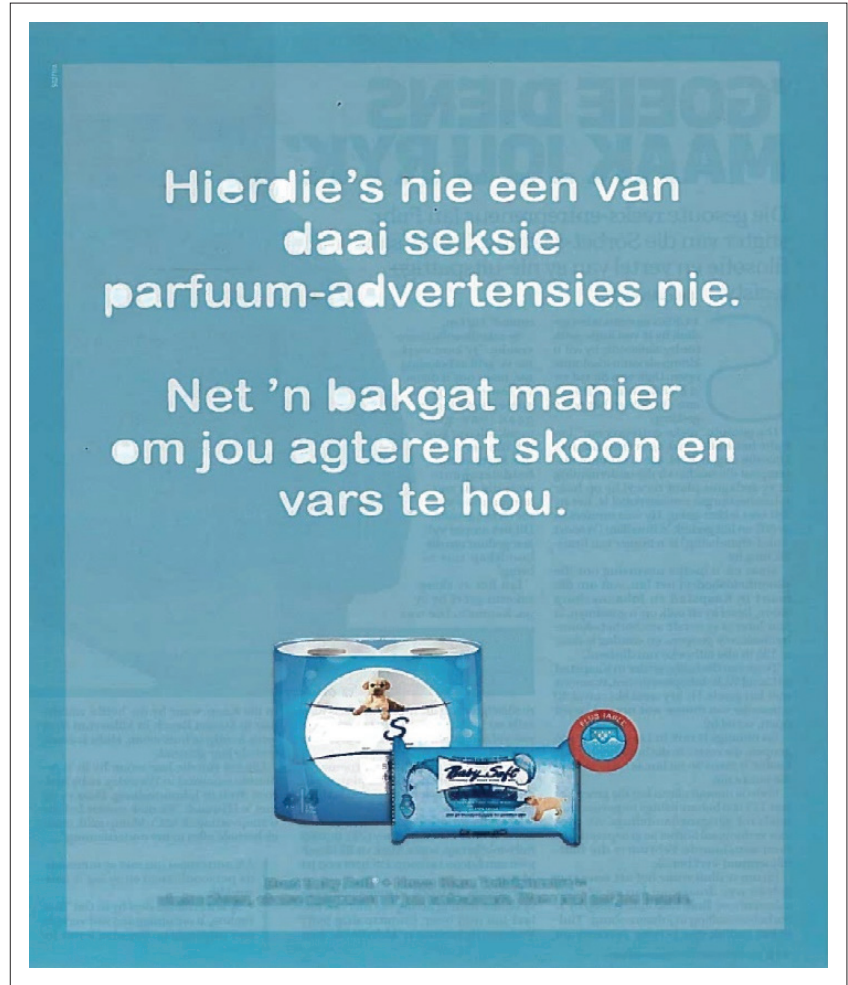

Bron: BabySoft, 2015, 'BabySoft-advertensie', Huisgenoot, November, n.p FIGUUR 12: BabySoft-toiletpapierprodukte.

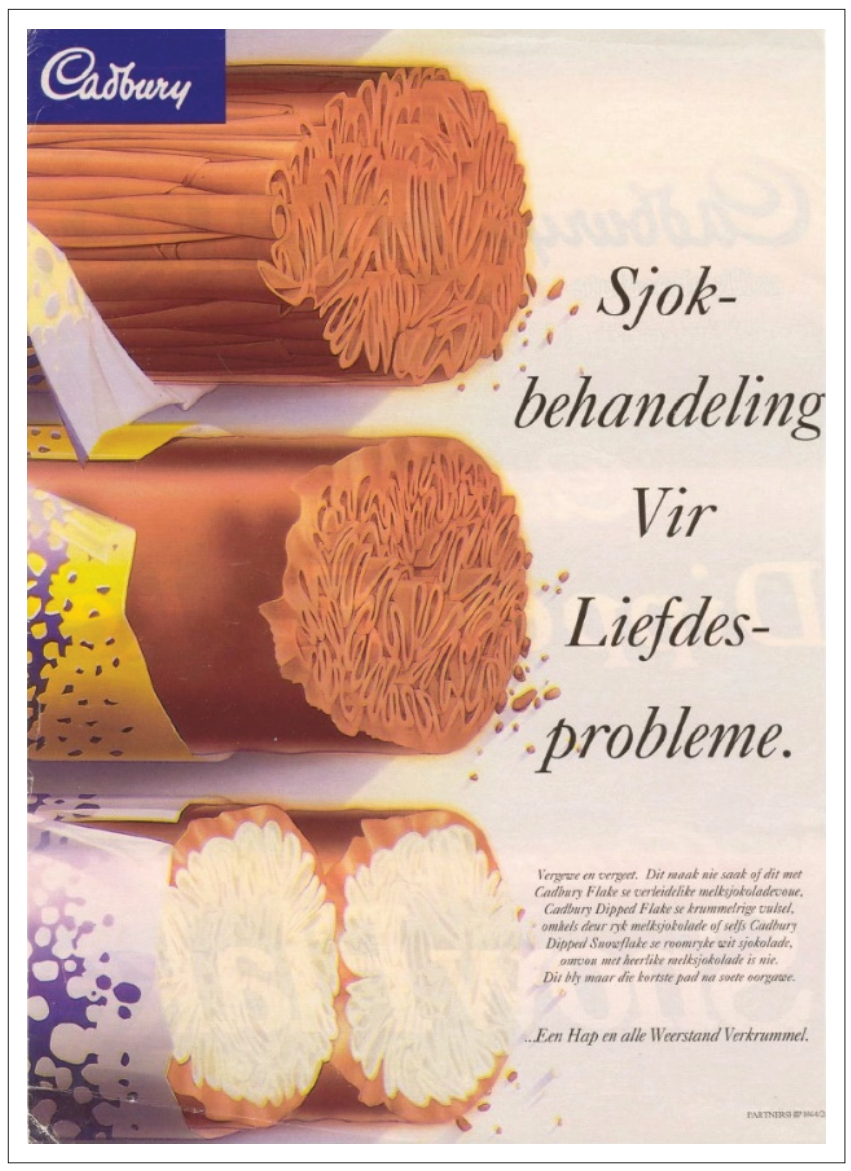

Bron: Cadbury Flake, 2006, 'Cadbury Flake-advertensie', Huisgenoot, Maart, n.p. BabySoft, 2015.

FIGUUR 13: Flake-sjokolade van die Cadbury-handelsnaam. 
- Die visuele fokus van die advertensie wat intertekstueel (op pragmatiese vlak) herinner aan 'n muurprop (elektriese punte) is noodwendig nuttig om die taalspel tussen sjokoladebehandeling wat nuttig sou wees as skokbehandeling te aktiveer. Die afwyking op grafiese vlak wat die ortografie van Afrikaans betref met betrekking tot die gebruik van punte aan die einde van sinne, en die onnodige gebruik van hoofletters in die woord Liefdesprobleme en in die subopskrif: 'Een Hap en alle Weerstand Verkrummel' val natuurlik ook op. Enkelwoordsinne en -frases is dikwels aanvaarbaar op tekstuele vlak binne die minder-as-meer-beginsel in advertensies. Daar sal apart na die afwykings op sintaktiese vlak met 'n ander tersaaklike voorbeeld gekyk word.

- Flake-sjokolade van Cadbury is die ideale handelsnaam om enige skok of trauma te besweer en jou bloedsuiker te stabiliseer want niemand kan 'n Flake-sjokolade weerstaan nie.

\section{Pragmatiese vlak}

\section{Implikasie weens die oortreding van die} koöperatiewe beginsel:

- Virseker (korttermynversekering) (Figuur 14)

- Huisgenoot, April 2012

- trots AFRIKAANS. Subopskrif: Virseker. Jou verskering, jou mense, jou taal.

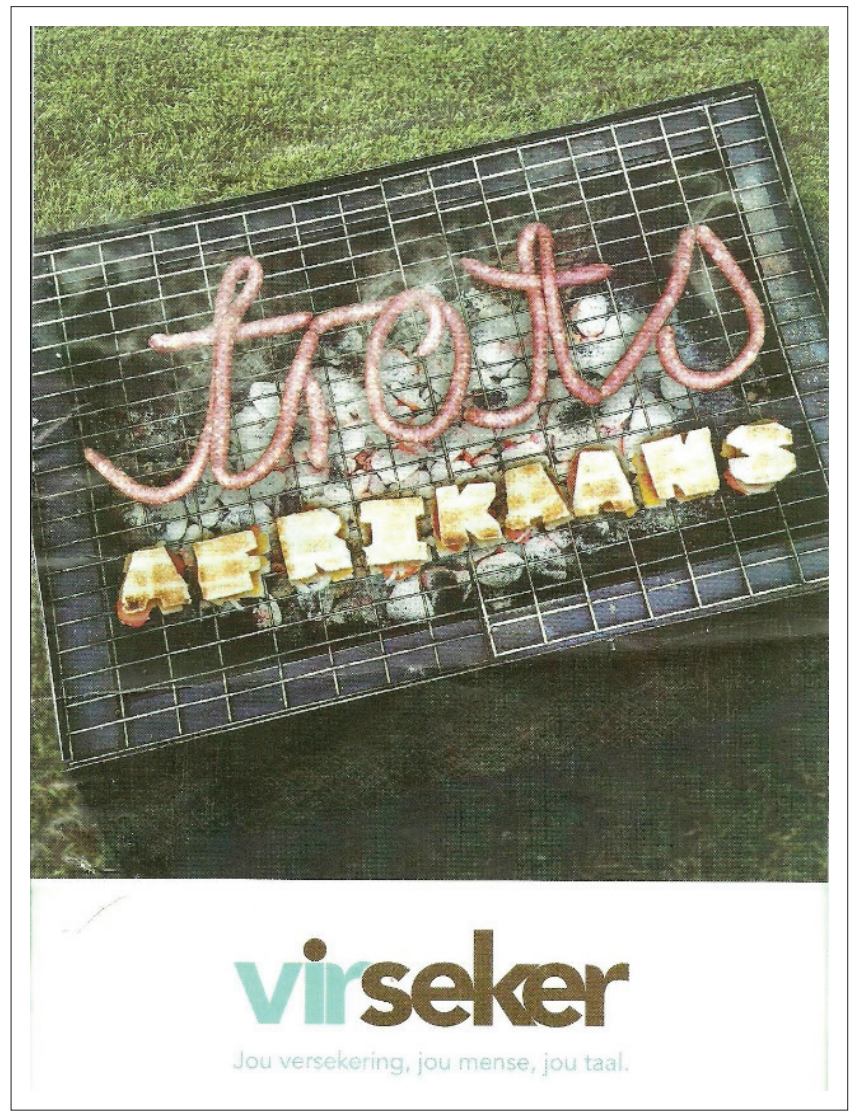

Bron: Virseker, 2012, 'Virseker-advertensie', Huisgenoot, April, n.p

FIGUUR 14: Virseker-korttermynversekering.
- Virseker is trots daarop om versekering in Afrikaans aan te bied.

- Vanuit 'n morfologiese beskouing en grafiese perspektief val die spel tussen die woorde vir seker en verseker beslis op en vanuit 'n sintaktiese perspektief is die advertensie soos ook vele ander in die ondersoek grootliks ondergeleksikaliseerd. Die implikasie en trefkrag van die advertensie is visueel geanker vanweë die oënskynlike irrelevansie van boerewors en braaibroodjies op'n braairooster spesifiek vir ' $n$ verskeringadvertensie; dit is trouens nie 'n advertensie vir vleis, 'n restaurant of braairoosters nie. Die feit dat slegs die woord Afrikaans in hoofletters geskryf staan en nie byvoorbeeld die besigheidsnaam, Virseker nie, hou waarskynlik funksioneel met die unieke posisionering van die maatskappy gerig op die Afrikaanse marksegment verband.

- Virseker is ' $n$ trots Afrikaanse versekeringsmaatskappy wat vir seker ook waarde aan die kultuurgoedere van die Afrikaanse gemeenskap (wat taal en eetgewoontes insluit) heg.

\section{Intertekstuele verwysing:}

- Exclusive Books-boekhandelaar (Figuur 15)

- Pendoring reklamekompetisiewenner: 2011; asook Huisgenoot, April 2011

- jou lag is 'n oopgebreekte granaat.

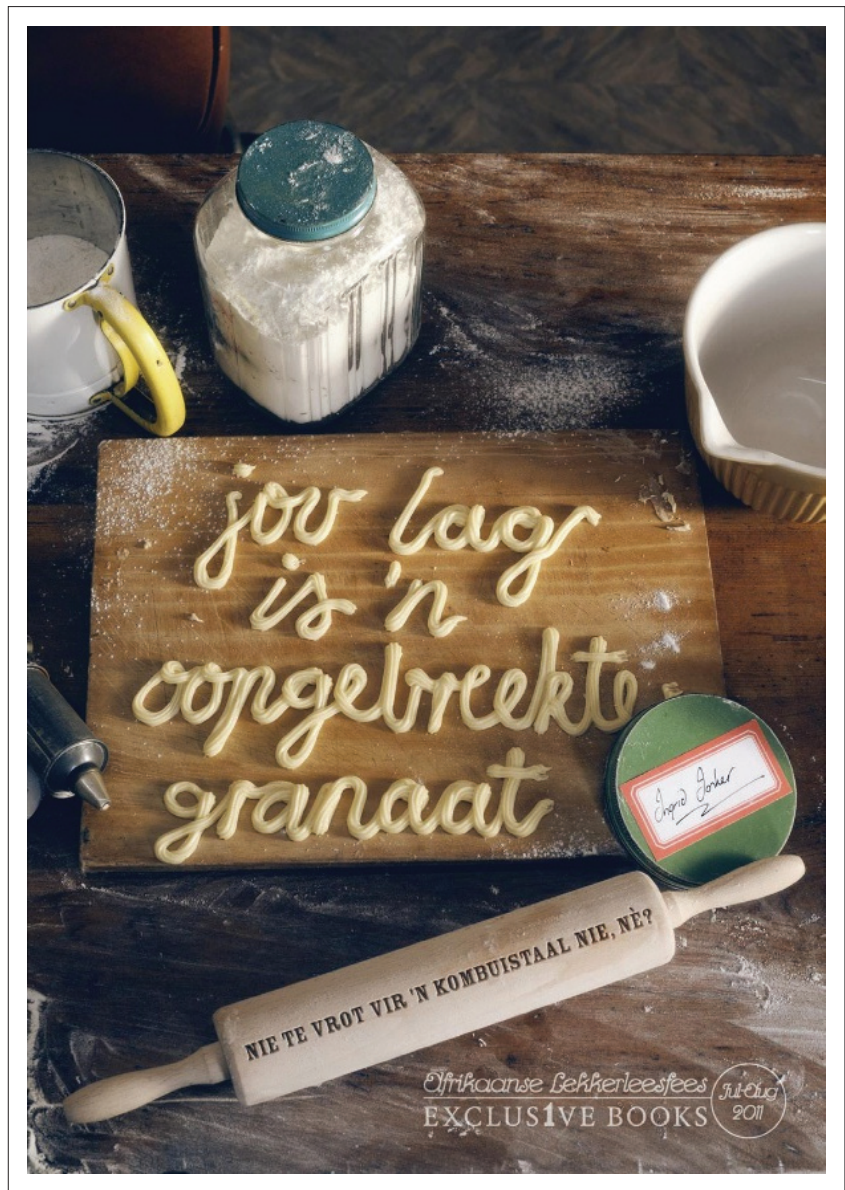

Bron: Exclusive Books, 2011, 'Exclusive Books-advertensie', Huisgenoot, April, n.p FIGUUR 15: Exclusive Books-boekhandelaar. 
- Subopskrif: NIE TE VROT VIR 'N KOMBUISTAAL NIE, NÈ?

- Boekliefhebbers en ingewydes van die Afrikaanse letterkunde het rede om oor die aanbod van boeke van Exclusive Books te glimlag.

- Die ouwêreldse kombuisware met koekroller, versiersuikerspuitstuk, glasmengbak, glasbottel met handgeskrewe etiket (Ingrid Jonker) help visueel om die bepaalde teikenmark die intertekstuele verband tussen die bekroonde Afrikaans digter, Ingrid Jonker, en die reël uit een van haar gedigte te laat trek. Die subopskrif op die koekroller verwys intertekstueel na Afrikaans se taalgeskiedenis en die stryd om amptelike erkenning, omdat dit lank voor 1925 dikwels net as kombuistaal (omgangstaal tussen minder intellektueles) geag is. Die miskenning van die grafiese norme wat die gebruik van leestekens en hoofletters in die opskrif en die ooraanbod van hoofletters in die subopskrif betref, kan waarskynlik funksioneel met die digterlike vryheid en die normdeurbrekings tekenend van die digkuns wat preskriptiewe grammatikareëls betref, verband hou.

- Exclusive Books bied 'n leesfees van boeke te koop vir die ingewyde Afrikaanse boekliefhebber wat vertroud is met die werk van digters soos Ingrid Jonker en kennis dra van die groei in die Afrikaanse taal- en boekbedryf.

\section{Bevindings}

Die onderstaande kenmerke is in elke voorbeeld se analise pertinent aangedui. Opsommend sluit die volgende opmerklike grammatikale kenmerke van gedrukte advertensietaal die volgende in:

- Die grafiese norme van Afrikaans word alternatiewelik in advertensies toegepas. Eie skryfkonvensies word gebruik, afwyking van die spellingsnorme van Afrikaans kom voor, leestekenkonvensies word funksioneel misken. Die afwykende gebruik van die norme hang dikwels saam met die beeld (image) van die bepaalde handelsnaam soos in die Virseker (versekerings-) voorbeeld. Die afwykings is op taalspel gerig wat op die handelsnaam fokus of om 'n aspek van die handelsnaam in die fokus te wil plaas.

- Die leksikonopgaaf van Afrikaans word in advertensies verbreed en dit blyk uit die opheffing van semantiese seleksiebeperkings en betekenisverbreding ter wille van taalspel; die norme van duidelikheid of eenduidige kommunikasie word ter wille van doelbewuste dubbelsinnigheid en bedoelde konnotasie opgehef.

- Die sintaktiese norme en sinsboureëls word opgehef sodat foute in advertensietaal aanvaarbaar word. Dit sluit die gebruik van bysinne as hoofsinne, sintaktiese onderleksikalisering (wat betref noodsaaklike boustene soos naamwoorde en werkwoorde) en onvoltooide sinne ter wille van verhoogde betrokkenheid in.

- Die stilistiese norme word vryer hanteer. Die norm van registervoorskrif word opgehef en verbreed deurdat die norme van taalsuiwerheid en die onderskeid tussen skryf- en spreektaal opgehef word; die norme van welvoeglike taal (gepastheid) word ter wille van teikenmark-afbakening verbreed.

- Die geledingsreëls van die morfologie van Afrikaans en toelaatbare klankkombinasies in Afrikaans word ter wille van kreatiwiteit en spel met die handelsnaam nie streng toegepas nie. Advertensies skep onsinnige woorde, oftewel geleentheidswoorde (wat ook soms die handelsnaam omvat) om aandag op die handelsnaam of op 'n aspek van die produk of diens te fokus.

- Die pragmatiese norme (Carstens 1997) wat met die koöperatiewe beginsel en die reëls van veral voorbereiding en relevansie verband hou, word doelbewus verbreek weens die genre-aard van advertensies (minder is meer) en die skep van intertekstuele verwysing wat die betrokkenheid van die teikenmark verhoog.

- Die ondersteunende tekstuele aspekte van die advertensieteks is 'n voorvereiste vir die oordrag van 'n intensionele maar meestal geïmpliseerde (bemarkings) boodskap.

Samevattend sou daar ook opgemerk kon word dat daar 'n groter ooreenkoms tussen skryftaal en spreektaal blyk te wees, veral wat die stilistiese norme betref. Dit sluit ook aan by wat Van der Horst in sy boek, Het einde van de Standaardtaal (2008:311) skryf: ' '.. en naar binnen toe blijkt de nagestreefde en veronderstelde homogeniteit grotendeels een fictie geweest, en we accepteren de variatie ...'

\section{Ten slotte}

Die talige aard van Afrikaans in die datastel is tekenend van die lewende aard van Afrikaans as groeiende organisme wat leef in reaksie op 'n inklusiewe sosio-politieke tydgees en bepaalde markkragte.

Die ingeligte taalgetroue (Steyn 2016) kan wel nie vir die verskuiwings en bedreigings vir Afrikaans se hoër funksies blind wees nie. Die inklusiewe tydgees verklaar die gekommodifiseerde vergestalting van Afrikaans anders as net Standaardafrikaans.

Steyn (2016:343) stel dit as 'n voorwaarde vir die ontstaan van 'n taalbeweging dat krities denkende mense insig in hulle vermoë tot beplanning toon. Hy haal uit N.P. van Wyk Louw se Versamelde prosa 2 aan wat stel dat 'n taalstryd twee rigtingopsies kan inneem, terug na die hunkering na 'n mooi verlede, of die (beter) opsie om as gewone burger' $n$ daaglikse stryd te kies om ook ekonomies vooruit te gaan.

Die aard van Afrikaans in die gedrukte publikasiesfeer blyk 'n simbolies instrumentele vergestalting te wees op die eise van markkragte in die hedendaagse sosiopolitieke tydgees wat inklusiwiteit beklemtoon. In die advertensiebedryf (hierby sou 'n mens die filmbedryf, musiekbedryf, uitgewersbedryf kon voeg) is die motivering vir bepaalde taalkeuses (ook in Afrikaanse tekste) dus ook 
finansieel gedrewe, want dit gaan om die inkomste van die kunstenaar, skrywer, filmmaker, handelsmerkeienaar en die erkenning wat die kopieskrywer in sy veld geniet. Nasionale en internasionale advertensiekompetisies (bv. Pendoring) is tekenend daarvan dat kopieskrywers as kunstenaars van die woord met mekaar meeding om pryse en erkenning en daarvoor moet hulle onder meer die taal as instrument (Afrikaans in sy verskeidenheid) funksioneel kan inspan.

'n Toekomstige vergelykende ondersoek sou aan die hand van die grammatikabeskrywing in die ondersoek (analiseraamwerk) kon vasstel hoe Afrikaans in bepaalde sfere, byvoorbeeld die advertensiebedryf teenswoordig normatief (grammatikaal) vergelyk met 'n vroeëre tydvak toe Afrikaans polities goed verskans was of meer eksklusief geposisioneer was.

\section{Erkenning \\ Mededingende belange}

Die outeur verklaar hiermee dat sy geen finansiële of persoonlike verbintenis het met enige party wat haar voordelig of nadelig kon beïnvloed het in die skryf van hierdie artikel nie.

\section{Literatuurverwysings}

7de Laan, 2008, 'Advertensie vir die sepie 7de Laan', You [Afrikaanse uitgawe: Huisgenoot], November, n.p.

Afrikaans.com, s.j., Afrikaans verkoop die meeste boeke in Suid-Afrika., geraadpleeg op 17 Januarie 2018, vanaf http://english.afrikaansipkContentID.com/newsheadlines/did-you-know/afrikaans-book-sales

Botha, R.P. \& Sinclair, M. (reds.), 1985, 'Norme vir taalgebruik', in Spil plus 10 Departement Algemene Taalwetenskap, Universiteit van Stellenbosch.

Cadbury Flake, 2006, 'Cadbury Flake-advertensie', Huisgenoot, Maart, n.p. BabySoft, 2015, 'BabySoft advertensie', Huisgenoot, November, n.p.

Carstens, W.A.M., 1997, Afrikaanse tekslinguistiek: 'n Inleiding, Van Schaik, Pretoria.

Carstens, W.A.M., 2011, Norme vir Afrikaans: Enkele riglyne by die gebruik van Afrikaans, 5 de uitg., Van Schaik, Pretoria.

Carstens, W.A.M. \& Bosman, N. (reds.), 2014, Kontemporêre Afrikaanse Taalkunde, Van Schaik, Pretoria.

Carstens, W.A.M. \& Bosman, N. (reds.), 2014, Normatiewe Taalkunde, Van Schaik, Pretoria.

Conradie, M.C. \& Van Niekerk, A., 2015, 'The use of linguistic tokenism to secure brand loyalty: Code-switching practices in South African print advertising', Language Matters 46(1), 117-138. https://doi.org/10.1080/10228195.2014.9 81570

De Beaugrande, R.A. \& Dressler, W.U., 1981. Introduction to text linguistics, Longman, London.

Dentyne, 2010, 'Dentyne-advertensie', Idees, Junie, n.p.
Department of Education, 2008, National Curriculum statement - Grades 10-12, Learning programme guidelines (general), Governant Printer, Pretoria.

De Villiers, M., 1977, 'Die plek van die normatiewe in die taalkunde', Taalfasette 22(23), 1-9. https://doi.org/10.1080/04966740.1977.10587988

Exclusive Books, 2011, 'Exclusive Books-advertensie', Huisgenoot, April, n.p.

Grice, P., 1989, Studies in the way of words, Harvard University Press, Cambridge.

Hoeken, H., Swanepoel, P., Saal, E. \& Jansen, C., 2009, 'Using message form to stimulate conversations: The case of tropes', Communication Theory 19, 49-65. https://doi.org/10.1111/j.1468-2885.2008.01332.x

Jaguar, 2012, 'Jaguar-advertensie', De Kat, Junie, n.p.

Kotzé, E., 2014, 'Afrikaans as besitting, en die vraagstuk van herstandaardisering', Tydskrif vir Geesteswetenskappe 54(4), 635-655.

Kotzé, E. \& Pretorius, F., 2016, 'Oor Monnemente gepraat - Afrikaans se eerste neëntig jaar', Tydskrif vir Geesteswetenskappe 56(2-1), 291-293.

Louw, N.P. van W, 1986, Versamelde prosa 2, Human \& Rousseau, Kaapstad.

Múller, D., 2003, Skryf Afrikaans van A tot Z, Pharos, Kaapstad.

Myers, G., 1994, Words in ads, Oxford University Press, New York.

National film and video foundation, s.j., Research reports 2017, viewed 17 January 2018, from http://nfvf.co.za/home/index.php?=87

Nutriphase, 2014, 'Advertensie vir Nutriphase eksklusief by Pick n Pay', Rooi Rose, Januarie, n.p.

Orange River Cellars, 2012, 'Orange River Cellars-advertensie', Huisgenoot, Junie, n.p.

Radio Sonder Grense, 2015, 'Radio Sonder Grense-advertensie', Huisgenoot, Julie n.p.

Renkema, J., 1987, Tekst en uitleg - een inleiding in de tekstwetenschap, Foris, Dordrecht.

Republiek van Zoid Afrika, 2015, 'Advertensie vir Republiek van Zoid Afrika', Huisgenoot, Junie, n.p.

Spur, 2007, 'Spur-advertense', Huisgenoot, Maart, n.p.

Statistics South-Africa, n.d. Census 2011, viewed 18 November 2017, from http:// www.statssa.gov.za/census/census_2011/census_products/Census_2011_ Census_in_brief.pdf

Stell, G., 2010, 'Afrikaanse spreektaalnormen en prescriptieve Afrikaanse normen Is er genoeg ruimte voor grammaticale diversiteit in het Standaardafrikaans?', Tydskrif vir Geesteswetenskappe 50(3), 418-442.

Steyn, J.C., 2016, 'N.P. van Wyk Louw se opvattings oor taalbewegings en die behoud van Afrikaans', Tydskrif vir Geesteswetenskappe 5(2-1), 335-354.

Suid-Afrikaanse Akademie vir Wetenskap en Kuns, 2017, Afrikaanse Woordelys \& Spelreëls, 11de uitg., Pharos, Kaapstad.

Universiteit van die Vrystaat, 2016, 'UV-Raad keur 'n nuwe taalbeleid goed', geraadpleeg op 01 November 2017, vanaf http://www.ufs.ac.za/af/template/ nuusargief-item?news $=6694$

Van der Horst, J., 2008, Het einde van de standaardtaal: Een wisseling van Europese taalcultuur, Meulenhof, Amsterdam.

Van Niekerk, A., 2008, 'A discourse-analytical approach to intertextual advertisements: A model to describe a dominant world-view', Southern African Linguistics and Applied Language Studies 26(4), 495-512. https://doi.org/10.2989/ SALALS.2008.26.4.7.679

Van Niekerk, A. \& Jenkinson, A., 2012, 'The use of controversy as an approach in South African advertising', Language Matters 43(1), 60-80.

Virseker, 2012, 'Virseker advertensie', Huisgenoot, April, n.p.

Vitaforce, 2006, 'Vitaforce Ladyvite advertensie', Huisgenoot, Junie, n.p.

Webb, V.N., 1985, Taalnorme en Afrikaans: 'n Geval van twyfel en vertwyfeling, in R.P. Botha \& M. Sinclair (reds.), bl. 70-107.

Woolworths, 2013, 'Woolworths-advertensie', Rooi Rose, Mei, n.p.

WWF, 2010, 'World Wide Fund for Nature-advertensie', Huisgenoot, Februarie, n.p. 